\title{
Stratigraphy of the
}

Kohat Quadrangle,

Pakistan

GEOLOGICAL SURVEY PROFESSIONAL PAPER 716-D

Prepared in cooperation with the Geological Survey of Pakistan under the auspices of the Government of Pakistan and the Agency for International Development, U.S. Department of State

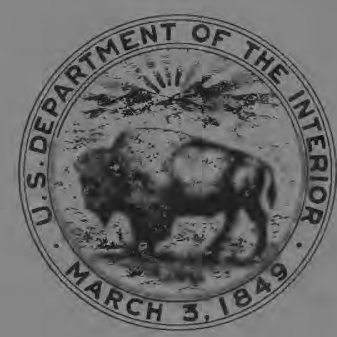


Stratigraphy of the

Kohat Quadrangle,

Pakistan

By CHARLES R. MEISSNER, JAN M. MASTER,

M. A. RASHID, and MUZAFFAR HUSSAIN

GEOLOGIGAL INVESTIGATIONS IN PAKISTAN

GEOLOGICAL SURVEY PROFESIONAL PAPER 716 -D

Prepared in cooperation with the Geological Survey

of Pakistan under the auspices of the Government

of Pakistan and the Agency for International

Development, U.S. Department of State

$A$ detailed description of stratigraphic units

which range from Jurassic to Pliocene in age

in the northwestern part of Pakistan

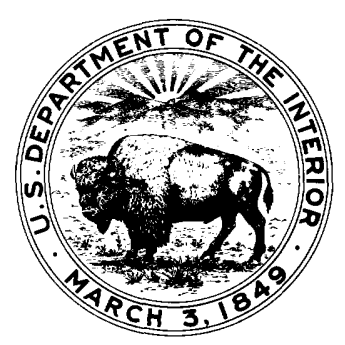

UNITED STATES GOVERNMENT PRINTING OFFIGE, WASHINGTON : 1974 
UNITED STATES DEPARTMENT OF THE INTERIOR

ROGERS C. B. MORTON, Secretary

GEOLOGICAL SURVEY

V. E. McKelvey, Director

Library of Congress catalog-card No. 73-600239

For sale by the Superintendent of Documents, U.S. Government Printing Office Washington, D.C. 20402 - Price $\$ 2.40$ (paper cover)

Stock Number 2401-02555 


\section{FOREWORD}

In 1956, the Geological Survey of Pakistan and the U.S. Geological Survey began a cooperative program to intensify the mapping and appraisal of the geological resources of Pakistan. The program was initiated under an agreement dated October 1955 between the Government of Pakistan and the International Cooperation Administration, predecessor of the Agency for International Development, U.S. Department of State. It included joint geological reconnaissance of unmapped areas, detailed mapping and appraisal of mineral districts, and development of facilities and staff to increase the capacity of the Geological Survey of Pakistan.

This volume entitled "Geological Investigations in Pakistan" is intended to present some of the more significant results of the cooperative program in Pakistan, which extended from 1956 to 1970 . It consists of papers that have been prepared by U.S. Geological Survey geologists and by their counterparts in the Geological Survey of Pakistan, summarizing the investigations believed to be most important for those interested in the geology and resources of Pakistan. More detailed information from these investigations, as well as reports from other studies made during the program, are available from the Geological Survey of Pakistan in Quetta. Much of the regional geological information obtained during this program, and from surveys made earlier, was summarized in a new Geological Map of Pakistan prepared cooperatively and published by the Geological Survey of Pakistan in 1964.

The cooperative program in Pakistan, which directly involved the services of about 110 professional personnel from Pakistan and 43 from the United States, operated successively under the direction of four Directors-General of the Geological Survey of Pakistan and three Chiefs of Party appointed by the U.S. Geological Survey. Program directors for Pakistan were E. R. Gee (195659), N. M. Khan (1959-64), A. F. M. M. Haque (1964-69), and A. M. Khan (1969-70). United States participation was supervised by J. A. Reinemund (1956-63), M. G. White (1963-66), and D. L. Rossman (1967-70), each of whom also served as senior geologic consultant to the Director-General.

Geologic specialists provided by the U.S. Geological Survey were supplemented by four mining engineers from the U.S. Bureau of Mines, who provided collateral assistance to the Pakistan Department of Mineral Development, and by a drilling specialist and an administrative specialist from the Agency for International Development. The Geological Survey of Pakistan, through the Ministry of Industries and Natural Resources, provided counterpart personnel facilities, and services for the program, and arranged cooperative support from the Pakistan Department of Mineral Development, as well as from the Pakistan Industrial Development Corporation, Pakistan Council of Scientific and Industrial Research, and other agencies concerned with resource development. 
This program would not have been possible without the excellent support of all agencies involved, both in Pakistan and the United States. The geological information and institutional growth obtained through this program should contribute significantly toward orderly economic and scientific development in one of Asia's largest and newest nations.

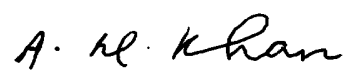

Abdul Mannan Khan, Director-General Geological Survey of Pakistan

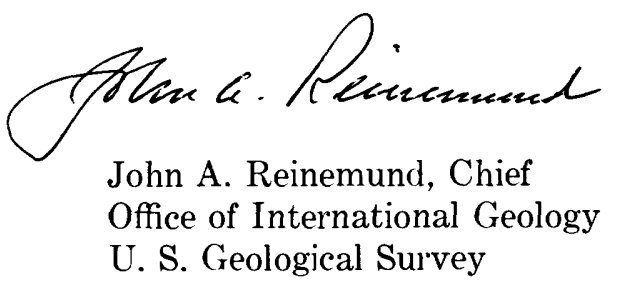




\section{CONTENTS}

Foreword

Abstract

Introduction

Location and extent of the area

Previous work -......

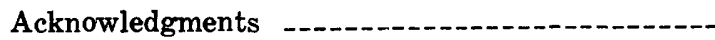

General geologic setting -

Stratigraphy

Precambrian or lower Paleozoic units _.......-... Pitao Ghar Formation -....... Attock Slate

Jurassic System _._. Datta Formation -...

Samana Suk Limestone

Cretaceous System -

Chichali Formation _......................

Lumshiwal Sandstone -..-_-

Darsamand Limestone

Paleocene Series

Hangu Formation -

Lockhart Limestone -................

Paleocene and Eocene Series

Patala Formation

Eocene Series

Panoba Shale _..........

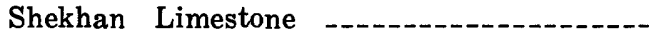

Bahadur Khel Salt and Jatta Gypsum ...--

Chharat Group

Mami Khel Clay

Kohat Formation

\begin{tabular}{|c|c|}
\hline $\begin{array}{r}\text { Page } \\
\text { III }\end{array}$ & Stratigraphy-Continued \\
\hline D1 & Miocene Series \\
\hline 1 & - \\
\hline 1 & Murree Formation \\
\hline 1 & Kamlial Formation \\
\hline 1 & Pliocene Series \\
\hline 2 & Siwalik Group \\
\hline 3 & Chinji Formation \\
\hline 3 & Nagri Formation \\
\hline $\begin{array}{l}3 \\
3\end{array}$ & Dhok Pathan Formation \\
\hline 7 & Measured sections \\
\hline 7 & Uch Bazaar \\
\hline 7 & Mami Khel \\
\hline 9 & Chilli Bagh _. \\
\hline 9 & South Gumbat \\
\hline 9 & Sumari Payan \\
\hline 9 & Banda Daud Shah \\
\hline 10 & South Lachi \\
\hline 10 & Jatta salt quarry \\
\hline 10 & Hukni \\
\hline 12 & Marai Bala \\
\hline 12 & Ghunda - \\
\hline 12 & 品- \\
\hline 12 & - \\
\hline 13 & 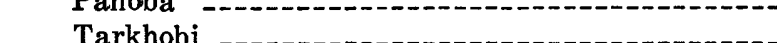 \\
\hline 13 & Shekhan Nala \\
\hline 14 & icant depositional features \\
\hline 14 & ces \\
\hline
\end{tabular}

Page

D15

15

15

15

16

16

16

17

17

18

18

19

20

20

20

21

21

22

23

23

24

24

25

25

26

26

27

27

29

\section{ILLUSTRATIONS}

[Plates are in pocket]

Plate 1. Geologic map and sections of the Kohat quadrangle, Pakistan.

2-5. Correlation of sections in the Kohat quadrangle, Pakistan:
2. Marai Bala to Dag.
3. Marai Bala to the Surghar Range.
4. Jata to Panoba.
5. Totaki to Hukni.

Figure 1. Index map of Pakistan, showing the location of the Kohat quadrangle

2. Chart showing probable correlation of stratigraphic nomenclature used by previous workers with that

in this report

3. Index map of the Kohat quadrangle, showing location of measured sections

\section{TABLE}

TABLE 1. Generalized section of the strata found in the Kohat quadrangle 

GEOLOGICAL INVESTIGATIONS IN PAKISTAN

\title{
STRATIGRAPHY OF THE KOHAT QUADRANGLE, PAKISTAN
}

\author{
By Charles R. Meissner, ${ }^{1}$ Jan M. Master, ${ }^{2}$ M. A. Rashid, ${ }^{2}$ and \\ MUZAFFAR HUSSAIN ${ }^{2}$
}

\begin{abstract}
The Kohat quadrangle (Geological Survey of Pakistan topographic sheet 38-0) is an area of approximately 4,000 square miles where sedimentary rocks have a total stratigraphic thickness of more than 25,500 feet. The oldest rocks, which crop out in the northeastern and northwestern parts of the quadrangle, are slate, slaty shale, and sandstone of Precambrian or early Paleozoic age. Jurassic, Cretaceous, Paleocene, Eocene, Miocene, and Pliocene sedimentary formations are also found in the Kohat quadrangle. Pleistocene sedimentary rocks may be present but were not recognized.

The rock sequence consists of 21 formations, six of which are formally defined for the first time.

The Jurassic System consists mostly of limestone; two subdivisions have been recognized. The lower half of the Cretaceous System is mostly marine sandstone; the upper half is mostly marine limestone. The Paleocene Series, which includes three formations, consists mostly of carbonate rocks but also contains some sandstone and shale. Of the Eocene Series, only rocks of early Eocene age are present in the Kohat quadrangle; they contain extensive deposits of gypsum, rock salt, marine limestone, and shale. A relatively thin section of the Murree Formation of Miocene age unconformably overlies lower Eocene rocks. It, in turn, is overlain by more than 19,000 feet of strata which make up the upper formation of the Miocene Rawalpindi Group and three formations of the Pliocene Siwalik Group.

Fourteen sections were measured by the authors in the Kohat quadrangle, and three other measured sections are referred to. This information was correlated with work done by Walter Danilchik and S. M. I. Shah in the Surghar Range on the southern border of the quadrangle and with work done by A. N. Fatmi of the Survey of Pakistan in the region west of the Kohat quadrangle.
\end{abstract}

\section{INTRODUCTION}

\section{PURPOSE AND SCOPE OF THE REPORT}

The territory from the Indus River west to the Afghanistan border and from Peshawar south to Bannu (Geological Survey of Pakistan topographic sheets 38-O and 38-K) was selected for concentrated

1 U.S. Geological Survey.

2 Geological Survey of Pakistan. mineral appraisal and geological mapping as an activity of the Mineral Exploration and Development Program undertaken by the Geological Survey of Pakistan and the U.S. Geological Survey on behalf of the Government of Pakistan and the U.S. Agency for International Development. Work began in October 1961 in the eastern part of this region, the Kohat quadrangle (fig. 1) (Survey of Pakistan topographic sheet 38-0). The initial emphasis was on the regional stratigraphy and measurement of outcrop sections; in addition, minerals reported in the literature were investigated and appraised, and care was taken to report on any previously unknown mineral deposits. Fieldwork for the present report, which summarizes the stratigraphy, was completed by April 1963, and final compilation of the geologic map of the Kohat quadrangle (pl. 1) was undertaken. A separate report (Rashid and others, 1965) summarizes the mineral data. A correlation of present stratigraphic nomenclature with previous usage is presented in figure 2.

\section{LOCATION AND EXTENT OF THE AREA}

The area covered by this report consists of approximately 4,000 square miles, between lat $33^{\circ}$ and $34^{\circ} \mathrm{N}$. and long $71^{\circ}$ and $72^{\circ} \mathrm{E}$. It includes parts of the Khyber Agency, Peshawar District, Kohat District, Attock District, Afridi Tribal Area, and the Mianwali District of Pakistan. The city of Peshawar is on the northern border; the Surghar Range, on the southern border. The terrain is mostly mountainous but is covered with a network of fairly good roads. The town of Kohat, near the center of the area, was field headquarters.

\section{PREVIOUS WORK}

The Kohat region has received the attention of geologists for a long time because of its salt deposits. Burnes (1832) published the earliest known re- 


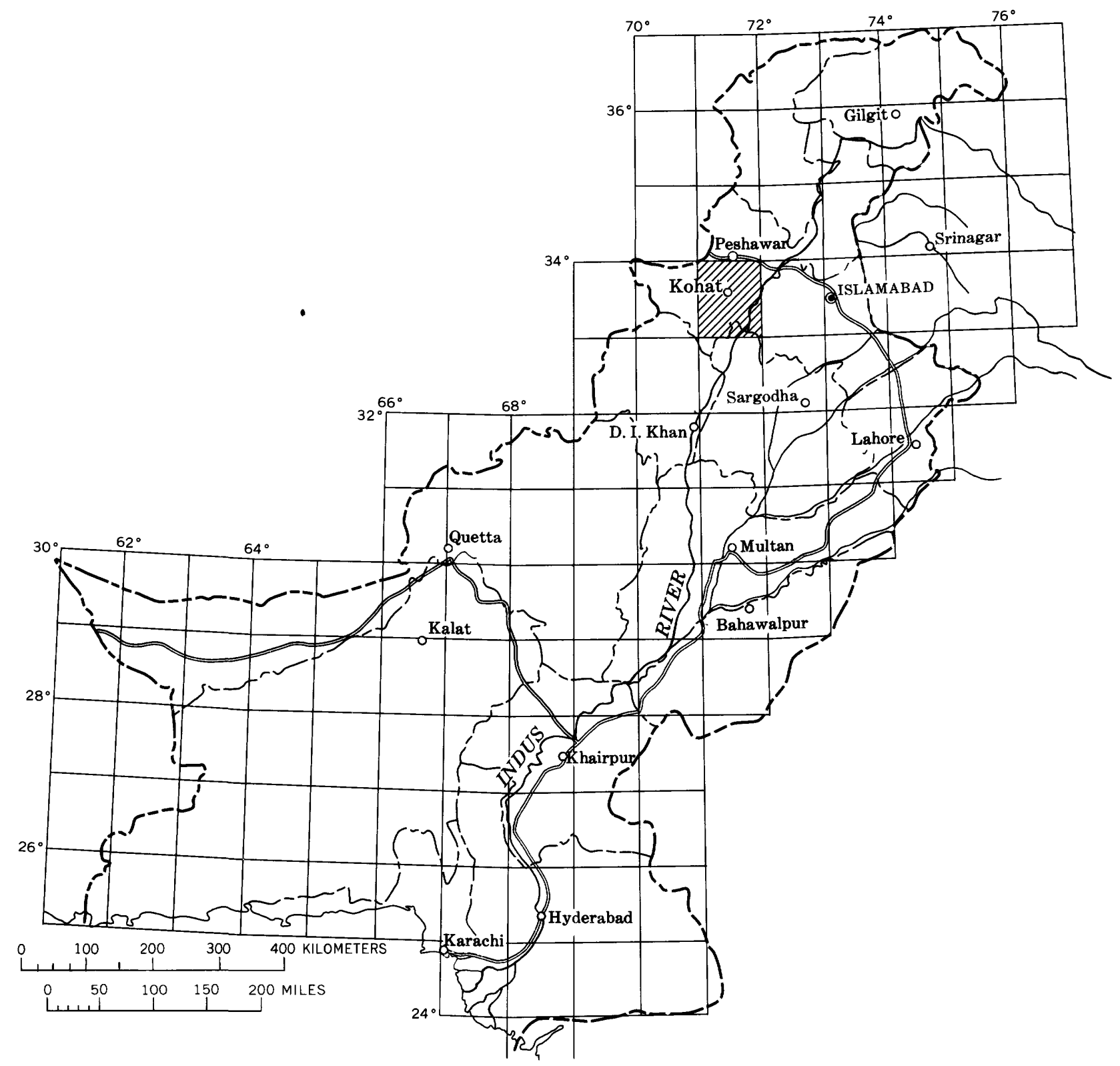

FIGURE 1.-Index map of Pakistan, showing the location of the Kohat quadrangle.

port on the salt deposits of the region. The salt mines of Kohat are probably the ones referred to by Karsten (1846) in an article published in the "Lehrbuch der Salinenkunde" at Berlin. Fleming (1853) referred to the salt of the Kohat area in a letter published by the Geological Society of London in 1853.

Oldham (1864) was the first geologist to describe the salt mines of the area. None of these early workers, however, reported in detail on the geology of the salt or of the region in general. A generalized account of the geology by Wynne (1875) was published by the Geological Survey of India.

\section{ACKNOWLEDGMENTS}

S. M. N. Rizvi and A. N. Fatmi, Geological Survey of Pakistan, were the first to familiarize the authors with the general geology of the Kohat region. Fossil determinations and age identifications were made by Edward B. Fritz, U.S. Geological Survey. Mr. Bandial, Deputy Commissioner, Kohat District, was helpful in facilitating travel and residence in the area. Mr. Khan, Superintendent of Police, Kohat District, provided assistance when necessary in the course of work in some areas. 


\section{GENERAL GEOLOGIC SETTING}

The Kohat quadrangle is underlain by sedimentary rocks, which range in age from Jurassic to Pliocene. In the northeastern and northwestern corners of the quadrangle, slate, slaty shale, and sandstone of Precambrian or early Paleozoic age are found (pl. 1). Triassic and possibly Permian rocks which crop out in isolated areas along the southern border of the region are related to those in the Salt Range to the southeast and are not described in this report.

The sedimentary sequence in the quadrangle has a stratigraphic thickness of more than 20,000 feet, measured from the base of the lowermost exposed Jurassic rocks through the Nagri Formation of Pliocene age. The Dhok Pathan Formation of Pliocene age, which conformably overlies the Nagri Formation, was not measured but has an estimated exposed thickness of more than 5,500 feet. The entire sequence is -intensely folded and faulted.

In the northern part of the quadrangle, the southern half of a broad topographic basin is bounded by mountains composed mostly of tightly folded and faulted Paleocene, Cretaceous, and Jurassic limestone, sandstone, and shale having a total stratigrapic thickness of about 3,600 feet. This arcuate range, 7 to 14 miles wide and concave northward, is the result of uplifting. Generally, the northern and southern flanks are in fault contact with younger rocks. Strike faults and imbricate structure are present within the range.

South of this range is a broad belt, 16 to 25 miles wide from north to south, underlain by rocks of Eocene and Miocene age. The Eocene sequence consists of limestone, clay, salt, and gypsum that total at least 1,700 feet in exposed stratigraphic thickness. The Miocene sequence consists of sandstone, siltstone, shale, and clay, that total about 2,200 feet in exposed stratigraphic thickness. These rocks have been tightly folded and form narrow ridges of lower altitude than the range of older rocks to the north. The ridges are separated by broad flat valleys. Overturning and thrust faulting of the southern flanks of the anticlines are common. The ridges of Eocene and Miocene rocks trend northeast in the eastern part of the quadrangle and east in the western part.

Immediately south of the belt of Eocene and Miocene rocks, most of the surface is underlain by Pliocene strata which occupy most of the southern third of the quadrangle and are composed of interbedded sandstone, siltstone, and clay containing conglomerate lenses. Total stratigraphic thickness is more than 17,000 feet. The Pliocene rocks form a rugged mountain terrain of about the same altitude as the belt of Eocene and Miocene rocks to the north.

\section{STRATIGRAPHY}

The stratigraphic nomenclature used in this report is based on the recommendations and decisions of the Stratigraphic Committee of Pakistan. Since 1961, the Stratigraphic Committee has been holding meetings on the stratigraphy of Pakistan, the object of which is the preparation of a revised Stratigraphic Lexicon of Pakistan. This lexicon has not been published yet, but for the most part the stratigraphic names used in this report are in accordance with the recommendations of the committee.

The stratigraphy of the Kohat quadrangle is described from 17 widely spaced, measured outcrop sections; their location is shown in figure 3. A total of 41,547 feet of section was measured, sampled, and described. There is no continuous outcrop of the entire sedimentary thickness, but it can be inferred from the composite of several sections, measured within the area. The rock sequence consists of 21 formations, six of which are herein formally defined for the first time. Many fossil analyses and age identifications were made; when no diagnostic fossils were available, age classification as established by earlier workers was used. A generalized columnar section of the strata found in the Kohat quadrangle is shown in table 1.

\section{PRECAMBRIAN OR LOWER PALEOZOIC UNITS}

\section{PITAO GHAR FORMATION}

The oldest stratigraphic unit that crops out in the northeastern and northwestern parts of the quadrangle is a thick (not measured) formation composed of alternating beds of gray, thin- to mediumbedded, very hard sandstone and gray, hard, broken shale. No fossils were found. No reference to this sequence of sandstone and shale is known from the literature, and the sequence of rocks is herein named the Pitao Ghar Formation. The type exposure is at Pitao Ghar (lat $33^{\circ} 52^{\prime}$ N., long $71^{\circ} 57^{\prime} 30^{\prime \prime}$ E.), 9 miles S. $10^{\circ} \mathrm{W}$. of Nowshera.

A white quartzose sandstone that weathers to rusty brown is in contact with the Attock Slate on the south flank of Cherat Mountain, about 12 miles S. $10^{\circ} \mathrm{W}$. of Nowshera. No fossils were found in the unit. It is not certain whether this sandstone underlies or is interbedded with the Attock Slate, nor is its relationship with the Pitao Ghar Formation known. The sandstone strikes east into the Campbellpore quadrangle, where scheduled geologic mapping 


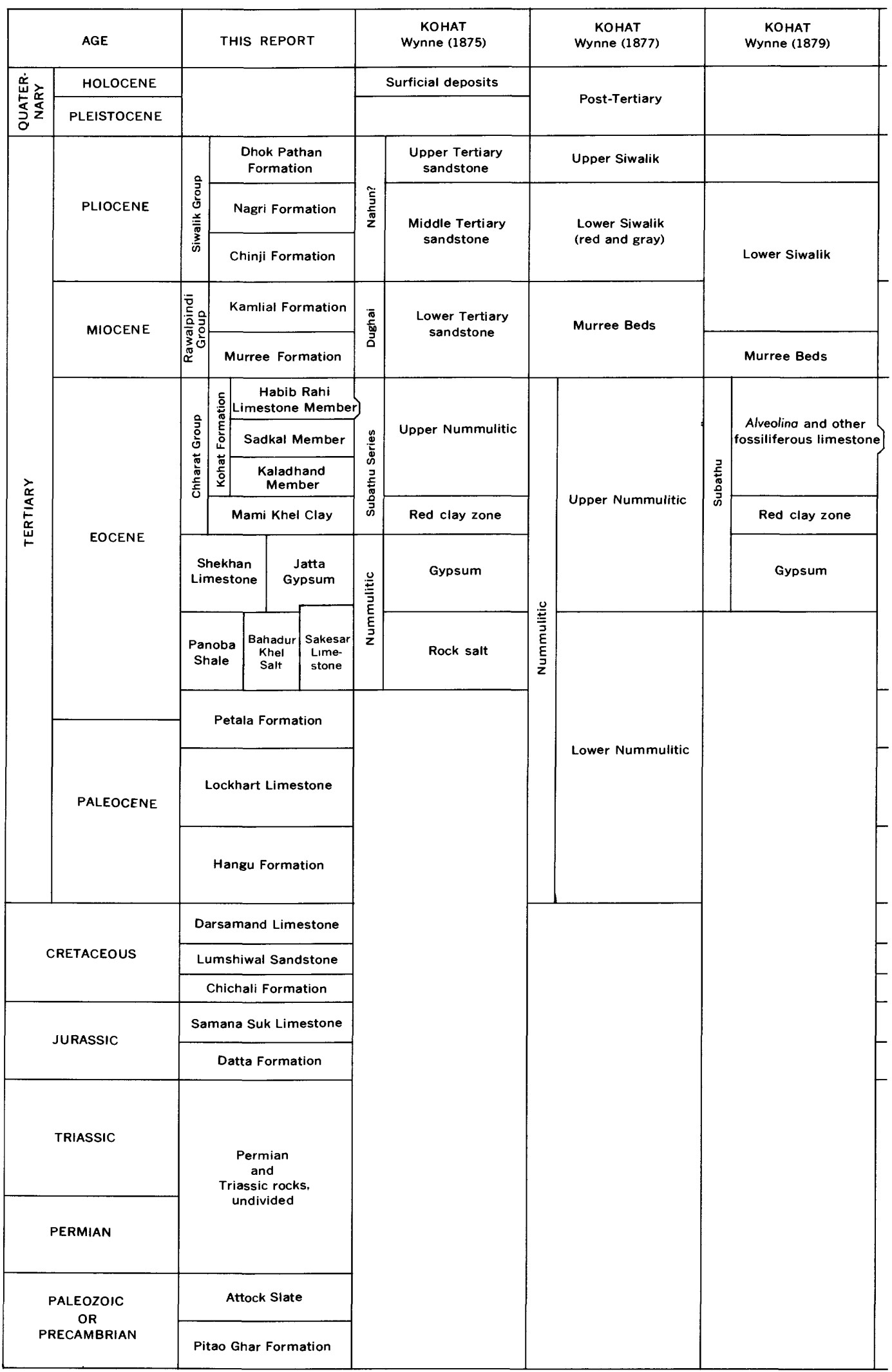

FIGURE 2.-Probable correlations of stratigraphic nomenclature 


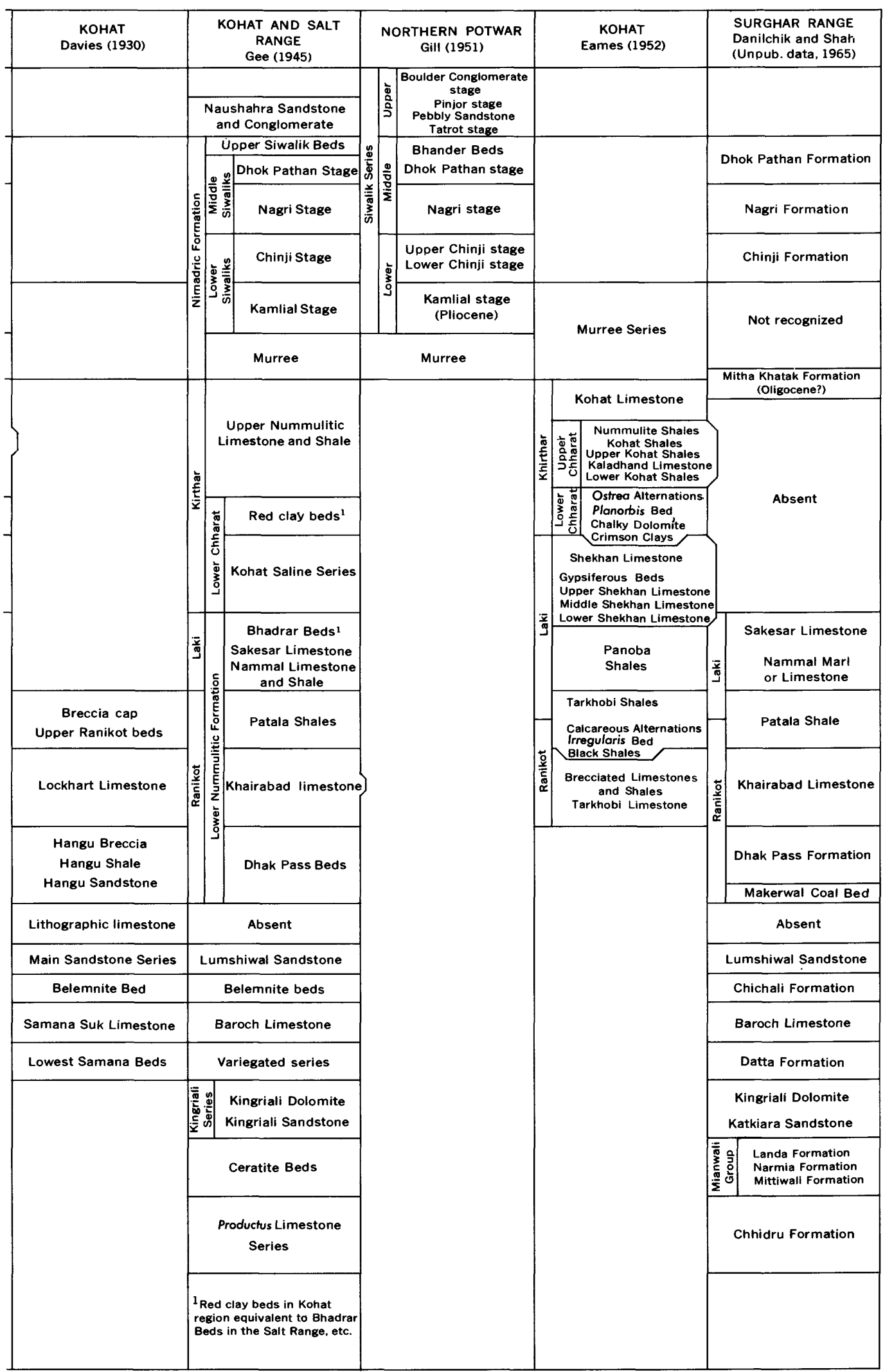

used by previous workers with that used in this report. 
TABLE 1.-Generalized section of the strata found in the Kohat quadrangle

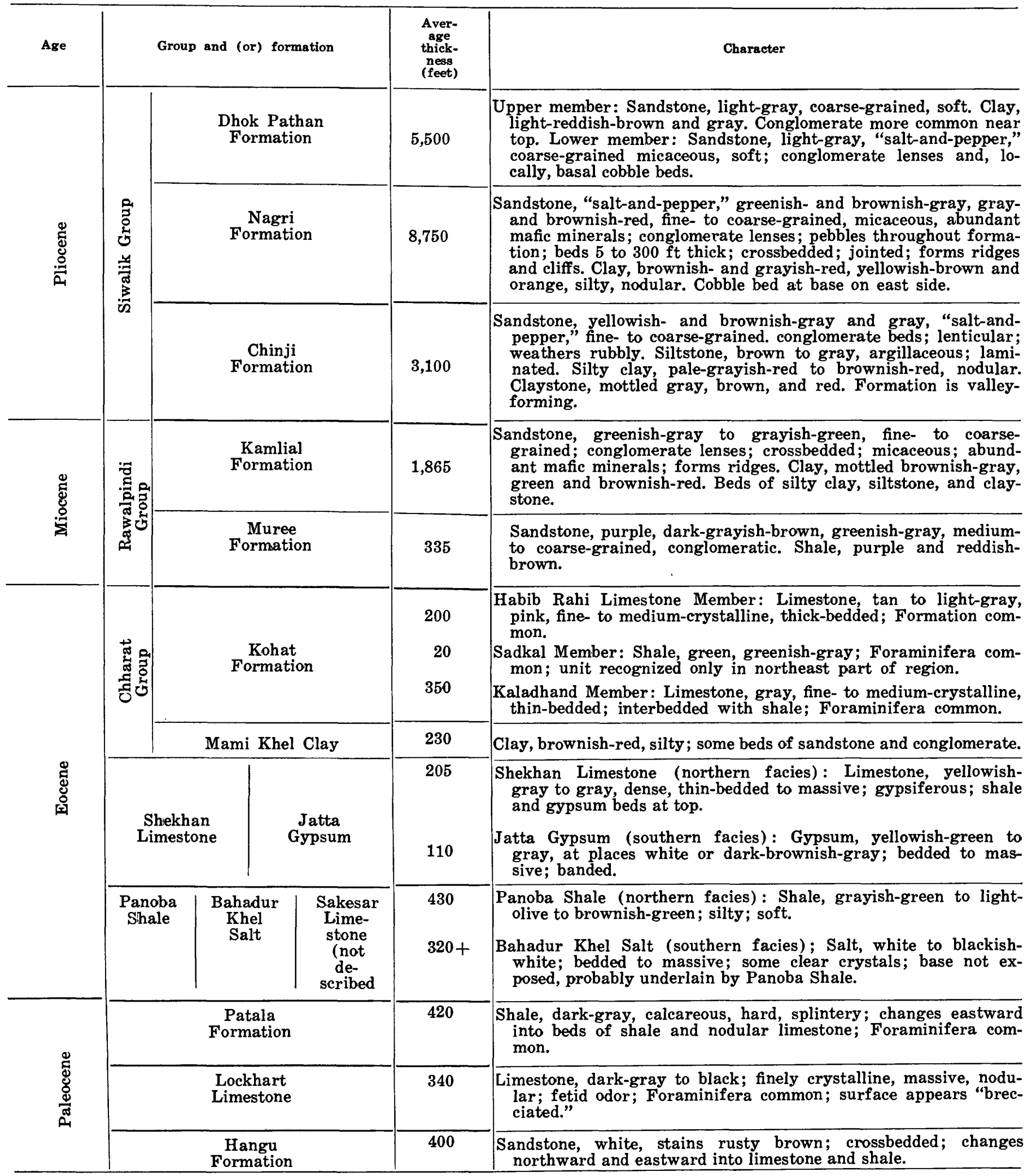


TABLE 1.-Generalized section of the strata found in the Kohat quadrangle-Continued

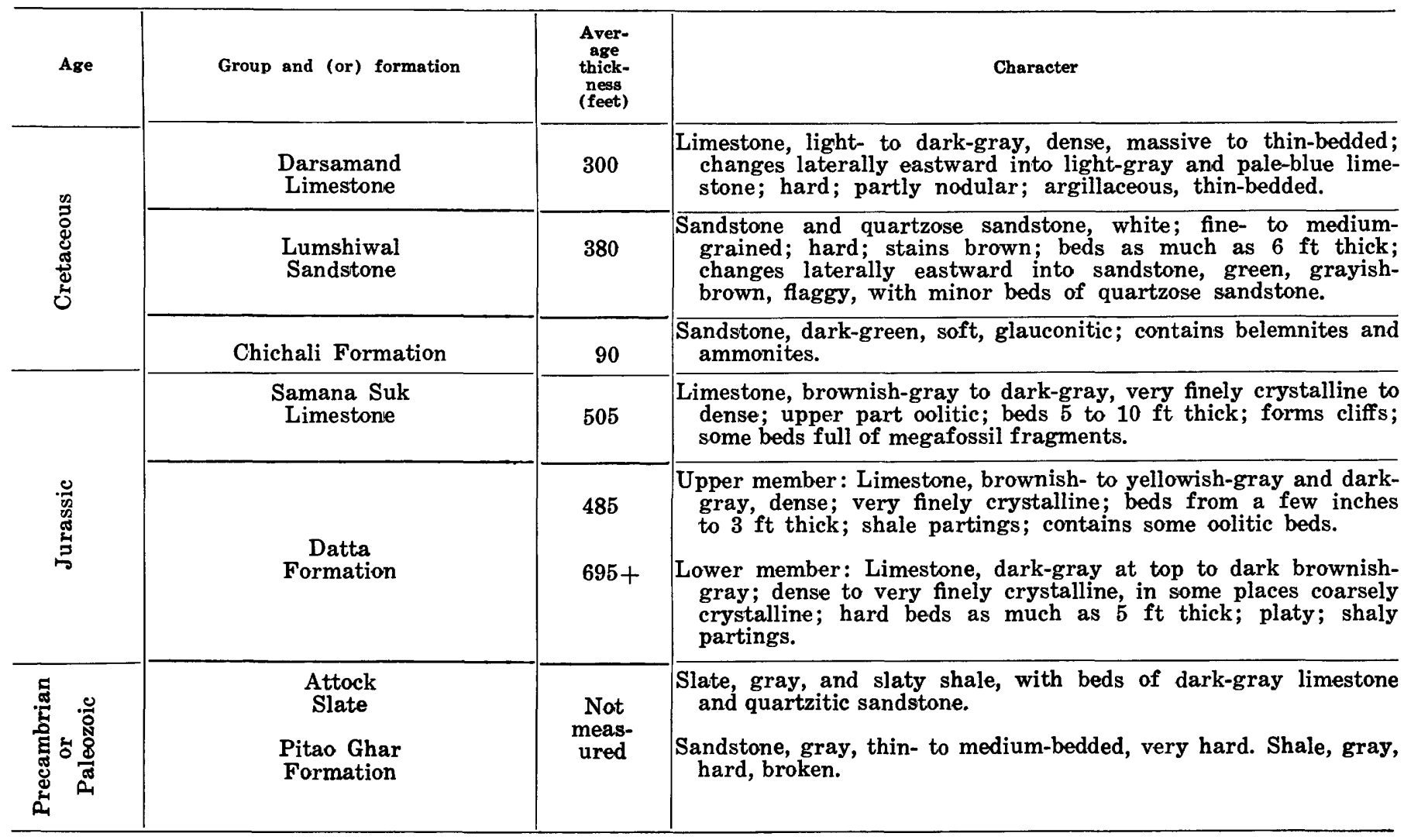

and stratigraphic work (1965) should help to better describe the unit.

\section{ATTOCK SLATE}

Overlying the Pitao Ghar Formation in apparently conformable contact is the Attock Slate, which consists of gray slate or slaty shale and beds of darkgray limestone, apparently without fossils. This stratigraphic unit was named by Wynne (in Wynne and Waagen, 1872, p. 333) after the town of Attock (lat $33^{\circ} 53^{\prime}$ N., long $72^{\circ} 17^{\prime} \mathrm{E}$.) on the Indus River. It is identical with the "slate series" (Middlemiss, 1896, p. 10) in the Hazara District, where it underlies Permian or Carboniferous rocks with marked unconformity.

The only place where the Attock Slate was included in a measured section during the present investigation was at Dag in the northeastern part of the quadrangle, although the Attock Slate also crops out in the northwestern part of the region near the Khyber Pass. At the Dag section, the Attock Slate is unconformably overlain by rocks of Paleocene age (pl. 2).

\section{JURASSIC SYSTEM}

The oldest rock overlying the Attock Slate is limestone of probable Jurassic age on the northern and southern flanks of Cherat Mountain in the northeastern part of the Kohat quadrangle (fig. 3). Jurassic limestone is not found on the crest of the mountain, where Paleocene, Eocene, and Miocene rocks unconformably overlie Attock Slate or the Pitao Ghar Formation. These observations suggest that Cherat Mountain was either above sea level during Jurassic time, or that Jurassic and possibly Cretaceous rocks, if deposited, were eroded from the crest.

Jurassic limestone in some places has been altered to marble at its contact with the Attock Slate. This marble has been found on the northern flank of Cherat Mountain as well as at outcrops in the northwestern part of the quadrangle.

\section{DATTA FORMATION}

The Datta Formation was named by Walter Danilchik and S. M. I. Shah (unpub. data, 1965) for exposures of Lower Jurassic rocks in the Surghar 


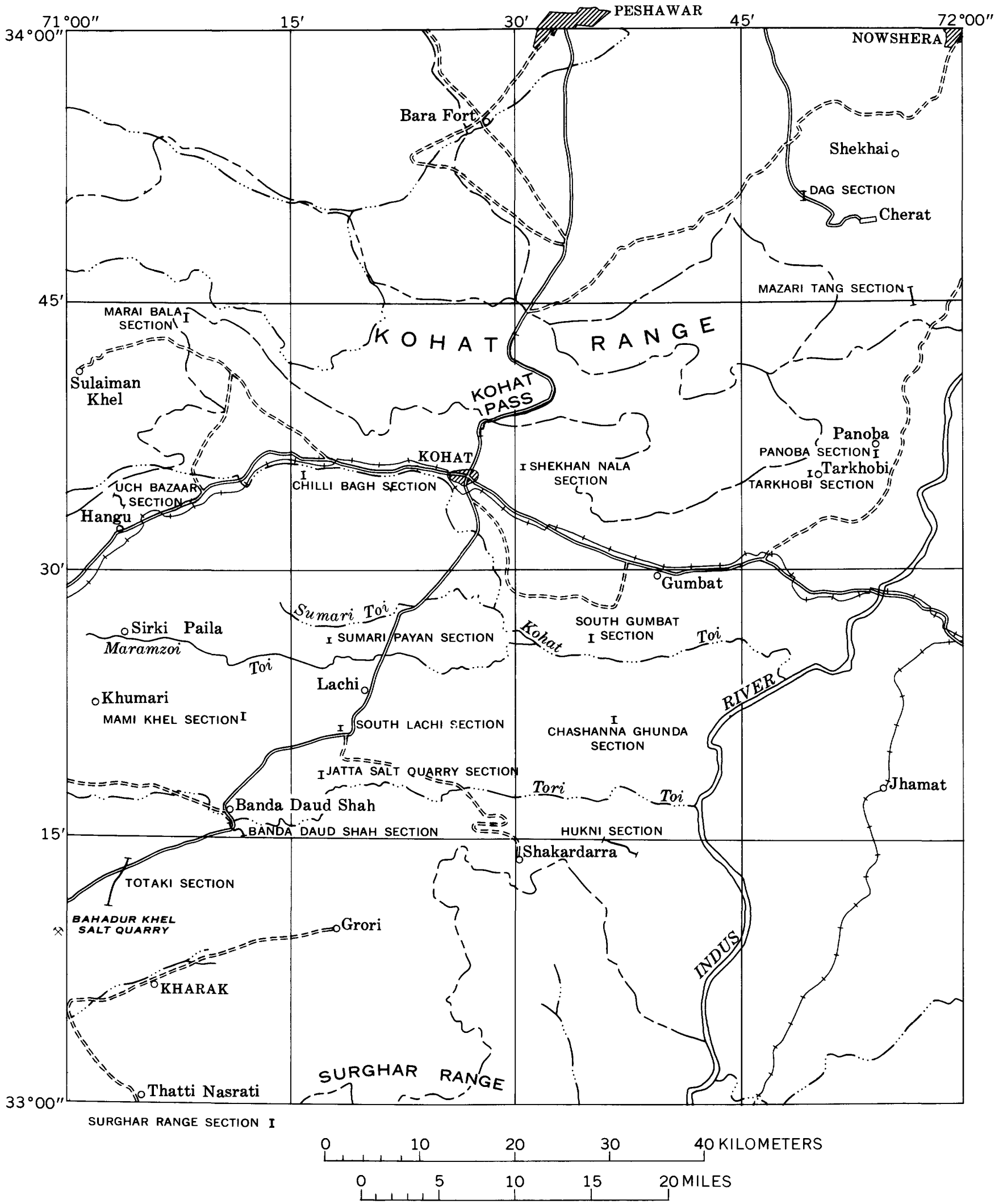

FIGURE 3.-Index map of the Kohat quadrangle, showing location of measured sections. The Surghar section is 9 miles southeast of Thatti Nasrati. 
Range on the south border of the Kohat quadrangle. It replaces the descriptive term "Variegated Series" of earlier authors.

The Datta Formation was measured and described at Maria Bala and Mazari Tang (fig. 3) ; it consists of thin- to medium-bedded limestone containing thin shale partings in places. At Marai Bala, the formation has been divided into an upper and lower member. The lower member has an exposed thickness of 695 feet of dark-gray limestone which is dense to very finely crystalline but in places is coarsely crystalline. Beds are a few inches to 5 feet thick, in places platy with shale partings. The upper member is 485 feet thick and is composed of dark-gray or brownish-gray limestone which is dense to very finely crystalline, in places coarsely crystalline and oolitic. Beds are a few inches to 3 feet thick. Both the lower and upper members contain layers of megafossil fragments, suggesting shallow-water deposition. The members form steplike scarps.

At Mazari Tang, only the upper member of the Datta Formation is exposed and is in contact with Cretaceous rocks; Upper Jurassic beds are absent (pl. 2). The Datta Formation at Mazari Tang is 602 feet thick and is composed of brownish- to yellowishgray, dense to very finely crystalline limestone in beds a few inches to 3 feet thick. The limestone has thin shale partings toward the bottom and contains layers of megafossil fragments.

A red shale facies believed to be of the Datta Formation is present near Sulaiman Khel, about 7 miles southwest of the Marai Bala section. A sandstone and shale facies of the Datta Formation is present on the north-central flank of the Kohat Range.

A cross section (pl. 3) drawn from the Marai Bala section southward approximately 50 miles correlates the Datta Formation there with that measured and described by Walter Danilchik and S. M. I. Shah (unpub. data, 1965) in the Surghar Range. The Datta Formation in the Surghar Range consists of interbedded sandstone and shale; at Marai Bala it is mostly limestone.

The upper contact of the Datta Formation with the Samana Suk Limestone is conformable except at Mazari Tang, where apparently the Samana Suk Limestone is absent and the Datta Formation is in unconformable contact with Cretaceous Chichali Formation. The upper contact at Mazari Tang contains very ferruginous casts and replicas of reworked belemnites and ammonites, suggesting an erosion surface.

\section{SAMANA SUK LIMESTONE}

The Upper Jurassic Samana Suk Limestone was first named by Davies $(1930$, p. 3) for rocks in the Samana Range near Hangu in the Kohat District. The correlation of this formation with the Baroch Limestone in the Surghar Range (fig. 2) was suggested by the present authors. In April 1964 the Stratigraphic Committee of Pakistan (1964b) recognized this correlation and agreed, because of precedence, to the use of the name Samana Suk Limestone (pl. 3) in place of Baroch Limestone.

The cliff-forming Samana Suk Limestone is dark gray to brownish gray and dense to very finely crystalline. Beds are 5 to 10 feet thick, well jointed, and have pitted surfaces. At Marai Bala the formation is 505 feet thick. The basal 25 feet consists of platy limestone; the uppermost beds are oolitic and in places contain Foraminifera (Bolivina, Rotalia, Nautiloculina oolithica) and megafossil fragments.

The upper contact of the Samana Suk Limestone with the Chichali Formation is unconformable and in places is marked by an irregular ferruginous weathered surface.

\section{CRETACEOUS SYSTEM}

\section{CHICHALI FORMATION}

The Lower Cretaceous Chichali Formation, formerly known as the Belemnite beds (Oldham, 1892, p. 19) or Belemnite shale, was named by Danilchik (1961) from exposures at Chichali Pass in the Surghar Range.

This formation is well exposed at the Mazari Tang section. It is 92 feet thick and is composed of darkgreen coarse-grained soft sandstone containing glauconite. The formation is crowded with belemnites, and A. N. Fatmi (oral commun., 1965) of the Geological Survey of Pakistan has collected diagnostic Early Cretaceous ammonites.

The outcrop of the formation is often stained yellowish brown. It forms a slope and bench above the cliff-forming Jurassic limestones.

The upper contact of the Chichali Formation is conformable with the Lumshiwal Sandstone.

\section{LUMSHIWAL SANDSTONE}

The Lower Cretaceous Lumshiwal Sandstone was named by Gee (1945) from a type locality in the Salt Range. The correlation of this formation with the Khadimak sandstone in the Parachinar quadrangle was suggested by the authors. The Strati- 
graphic Committee of Pakistan (1964a), in February 1964, agreed that the Lumshiwal Sandstone is equivalent to the Khadimak sandstone, and that the name Khadimak, proposed much later, should be dropped.

At Marai Bala, the Lumshiwal Sandstone is 450 feet thick and is composed mostly of very hard quartzose sandstone which is generally white but in places is stained brown. The sandstone is fine to medium grained, in beds as much as 6 feet thick. The beds are cut by two sets of well-developed joints and typically break into large blocks. About 70 feet below the top of the formation is a very ferruginous concretionary bed 10 feet thick, which, upon weathering, breaks into small blocks. This ferruginous band has been observed near Fort Lockhart in the Samana Range, about 17 miles southwest of the Marai Bala section. Black carbonaceous shale and brownishgreen soft medium-grained sandstone constitute the upper 20 feet. At Marai Bala, the upper contact of the Lumshiwal Sandstone with overlying Cretaceous rocks seems to be unconformable and contains abundant limonitic fossil casts, indicating that the surface was exposed to weathering before deposition of the overlying beds.

The Lumshiwal Sandstone at the Mazari Tang section is 224 feet thick and differs in character from the white very hard quartzose sandstone of Marai Bala. The basal 81 feet is grayish-brown fine-grained well-sorted hard sandstone, containing beds a few inches to 1 foot thick; it weathers to brownish green. Overlying this sandstone is 38 feet of light-brown to white sandstone that is medium grained, well sorted, hard, and composed of quartz grains. The next higher part of the Lumshiwal Sandstone is 86 feet of greenish-brown to brown fine-grained hard thinbedded flaggy sandstone. At the top of the formation, a 19-foot-thick zone is transitional with the overlying Upper Cretaceous Darsamand Limestone. The bottom of this zone is greenish-gray calcareous glauconitic sandstone that grades upward into grayishbrown to brown sandy, glauconitic limestone. The unconformity evident at the top of the Lumshiwal Sandstone at Marai Bala was not seen at Mazari Tang.

\section{DARSAMAND LIMESTONE}

The name Darsamand Limestone is proposed for Upper Cretaceous rocks exposed at the locality of Darsamand, about 18 miles west of the Kohat quadrangle in the Parachinar quadrangle (Meissner and others, 1973). This unit has also been recognized by the authors in the Marai Bala, Mazari Tang, and Uch Bazaar sections of the Kohat quadrangle (pls. $2,3)$.

At Marai Bala, the limestone is 400 feet thick and is described in three units. The lower unit is $\mathbf{5 0}$ feet thick and consists of brownish-gray hard thickbedded (beds as much as $10 \mathrm{ft}$ thick) limestone. It breaks into thin sharp plates, which give a metallic sound when struck with a hammer. The base of this unit is sandy, fossiliferous, and glauconitic. The middle unit is 270 feet thick and consists of light- to dark-gray dense hard thin-bedded (3 in. to $1 \mathrm{ft}$ ) limestone, which breaks with a conchoidal fracture and contains shale partings. It weathers into nodules. The upper unit is 80 feet thick and is transitional into overlying Paleocene beds. It is composed of nodular argillaceous limestone that grades upward into light-gray calcareous shale. Globotruncana sp. has been found in the Darsamand Limestone at Marai Bala up to the middle of the upper transition zone. In general, the Darsamand Limestone is slope forming.

At the Mazari Tang section (pl. 2), on the east side of the Kohat quadrangle, the Darsamand Limestone is 195 feet thick and consists of light-gray to gray dense argillaceous thin-bedded (beds a few inches thick) limestone, which weathers into seminodular pieces. Weathered outcrops of the limestone appear pale blue and chalky and form slopes. Its upper contact with overlying Paleocene rocks is transitional.

At the Uch Bazaar section, only the upper 200 feet of the Darsamand Limestone was measured. The limestone is gray finely crystalline, hard, and massive and forms a cliff. There is a facies change from bedded limestone with shale partings at Marai Bala to massive limestone at Uch Bazaar (pl. 2). The upper surface of the Darsamand Limestone at Uch Bazaar is weathered, which suggests a local unconformity with overlying Paleocene rocks.

The Darsamand Limestone is absent in the Makarwal area of the Surghar Range, where the Lower Cretaceous Lumshiwal Sandstone is in contact with overlying Paleocene rocks (pl. 3). There may have been tectonic uplift after the deposition of the Lumshiwal Sandstone in the Surghar Range area, so that Darsamand Limestone was not deposited.

\section{PALEOCENE SERIES}

HANGU FORMATION

The name Hangu sandstone was proposed by Davies $(1930$, p. 9) for the sandstone formation 
overlying Upper Cretaceous limestone north of Hangu. This sandstone sequence can be seen at the Uch Bazaar section, 2 miles north of Hangu, but it becomes limestone and shale, in places containing sandstone, northward and eastward in the Kohat quadrangle (pl. 2). Lateral facies changes of the Hangu sandstone to limestone and shale were observed by the authors, who have changed the name to Hangu Formation to include lateral lithologic changes. The Stratigraphic Committee of Pakistan (1964b), in their April 1964 meeting, accepted the name Hangu Formation to replace the name Hangu sandstone. At the same time, the Committee discussed the relationship of the Dhak Pass Formation of the Surghar Range and the Hangu Formation. They decided that although both formations occupy the same stratigraphic position, they are lithologically distinguishable from each other; therefore, both formations are to be recognized in their respective areas.

The Uch Bazaar section contains about 215 feet of sandstone in the Hangu Formation, which is white but stained rusty brown and is composed of rounded medium-sized quartz grains and small limonitic nodules. It is crossbedded and contains conglomerate lenses composed of quartz and chert pebbles onequarter to one-half of an inch in diameter. Davies $(1930$, p. 9) described 2 to 20 feet of yellow fossiliferous clay at the top of the Hangu Formation, which he called the Hangu Shale; this clay was not seen at Uch Bazaar.

At the Marai Bala section, the Hangu Formation is entirely shale, 150 feet thick, overlying the Paleocene-Cretaceous transition zone. The remarkable change from the crossbedded sandstone at Uch Bazaar to this light-gray, hard and splintery, highly calcareous shale is possibly indicative of a change to deposition in deeper calmer waters at Marai Bala.

At the Mazari Tang section, the Hangu Formation is 587 feet thick and is composed of limestone, silty and argillaceous in part, and subordinate calcareous clay. The bottom unit is 294 feet thick and is composed of brownish-gray to dark-gray finely to coarsely crystalline limestone that is very hard, compact, thick bedded (2-30 ft), and cliff forming; it has a strong fetid odor when freshly broken. Above this unit is 96 feet of calcareous clay, fossiliferous limestone, and mottled-brown, yellow, and greenishgray argillaceous limestone. The argillaceous limestone is soft, earthy looking, and thin bedded. The fossiliferous limestone is gray, medium to coarsely crystalline, and hard. The next higher unit is 143 feet thick and is composed of fossiliferous light- brownish-gray dense to very finely crystalline limestone that is medium bedded $(1 / 2-3 \mathrm{ft})$ and partly nodular to seminodular. The top unit is 54 feet thick and is composed of light-brownish-gray silty limestone, dense to very finely crystalline, thin bedded, and nodular. The Hangu Formation at the Mazari Tang section contains diagnostic Paleocene Foraminifera.

The Hangu Formation is correlated with the Dhak Pass Formation in the Surghar Range (pl. 3). The base of the Dhak Pass Formation is approximately at the base of the "Makarawal coal" seam (Gee, 1938, p. 279-295), as defined by Walter Danilchik and S. M. I. Shah (unpub. data, 1965). The coal seam was not found in the Hangu Formation in the Kohat quadrangle.

The upper beds of the Hangu Formation are conformable with the overlying Lockhart Limestone.

\section{LOCKHART LIMESTONE}

The Lockhart Limestone was named by Davies (1930, p. 10) from exposures near Fort Lockhart, about 5 miles west of the border of Kohat quadrangle. This formation is recognized in the Kohat quadrangle and described from the Marai Bala, Uch Bazaar, Tarkhobi, and Mazari Tang sections.

The Lockhart Limestone has a fairly uniform lithology in each section but differs considerably in thickness. Only the basal part was examined in the Marai Bala section, where the limestone is brownish gray and forms steep cliffs. It is medium crystalline, thick bedded, hard, oolitic, and contains Foraminifera. At Uch Bazaar, the limestone is about 150 feet thick, dark gray to black, finely crystalline, massive, hard, and has a blocky appearance because of joints. At the Tarkhobi section, the exposed thickness of the Lockhart Limestone is 453 feet; the base cannot be seen, and the total thickness is unknown. It is light to dark gray, finely crystalline, massive, hard, and contains Foraminifera. The name Tarkhobi Limestone was proposed by Eames $(1952$, p. 166) for the thick limestone exposed at the Tarkhobi section. Regional work indicated that the Lockhart Limestone is equivalent to Eames' Tarkhobi Limestone. The name "Lockhart" takes precedence over Tarkhobi. At Mazari Tang, the Lockhart Limestone is $\mathbf{5 3 3}$ feet thick, light brown, and gray to dark gray, dense to finely crystalline, thick bedded, and hard. It is well jointed, contains Foraminifera, and forms a sheer cliff. The rock has a strong fetid odor when freshly broken.

The Lockhart Limestone weathers in places into rounded nodules and is brecciated, as was observed 
by Davies (1930, p. 10) in the lower part of the formation near Fort Lockhart. Here he called it Hangu Breccia, which is now included in the Lockhart Limestone.

The authors correlate the Lockhart Limestone with the Khairabad Limestone (Gee, 1935, p. 67) in the Surghar Range (fig. 2). The Stratigraphic Committee of Pakistan (1964b) resolved, in their April 1964 meeting, that the two formations are equivalent and that the term Lockhart Limestone should be extended to include the Khairabad Limestone (pl. 3).

The upper contact is conformable with the Patala Formation.

\section{PALEOCENE AND EOCENE SERIES PATALA FORMATION}

The name Patala Formation has been derived from the name Patala shales that Davies and Pinfold $(1937$, p. 7 ) applied to rocks in the Patala Nala in the Surghar Range. The authors correlated the Tarkhobi Shales of Eames (1952, p. 166-167) with the Patala shales in the Kohat area but, because of considerable lithologic variation, proposed the name Tarkhobi Formation. The Stratigraphic Committee of Pakistan (1964b) in April 1964, decided to accept the earlier used name, Patala, instead of Tarkhobi; hence the name Patala Formation for these rocks.

The Patala Formation in the Kohat quadrangle is described from the Uch Bazaar, Tarkhobi, Panoba, and Mazari Tang sections (pl. 2). At Uch Bazaar, the formation is partly covered, and at Panoba and Mazari Tang, incomplete sections are exposed. A complete sequence of the Patala Formation is exposed at Tarkhobi, where 447 feet of gray splintery shale contain beds of silty shale and argillaceous limestone. The limestone beds contain Foraminifera. The shale contains limonite concretions and weathers to white. Eames (1952) found early Eocene Foraminifera near the top of the Patala Formation at Tarkhobi and there drew a faunal break; the fauna below this break are Paleocene in age, and, above it, Eocene in age. Eames subdivided the Eocene part into Calcareous Alternations, Irregularis Bed, and Black Shales. No lithologic break between the Eocene and Paleocene parts of the Patala Formation can be recognized in the field.

The exposed thickness of the Patala Formation in the Mazari Tang section is 604 feet. Its upper part is in fault contact with Cretaceous limestone. The bottom unit of the Patala is 138 feet thick and is composed of mottled brown, yellow, and gray silty limestone that is highly fossiliferous and weathers into nodular and seminodular pieces. The next higher unit is 225 feet thick and consists of gray, brownishgray, or dark-gray finely crystalline to mediumcrystalline thick-bedded nodular limestone. The third unit consists of more silty limestone that is 102 feet thick, mottled brownish gray, earthy, argillaceous, thin bedded, nodular, and very fossiliferous. The top unit is 139 feet thick and is composed of light- to dark-brownish-gray fossiliferous limestone that is finely crystalline and hard. Beds are as much as 5 feet thick. The rock has a strong fetid odor when freshly broken. The exposed part of the Patala Formation at Mazari Tang is entirely of Paleocene age.

The Patala Formation is conformable with the overlying Panoba Shale at the Panoba section.

\section{EOCENE SERIES \\ PANOBA SHALE}

The Panoba shales were named by Eames (1952, p. 167, 169), and the Stratigraphic Committee of Pakistan has recommended the formal name Panoba Shale. Eames' type locality is a section near Panoba village on the east side of the Kohat quadrangle (fig. 3). At Panoba, the shale is 335 feet thick and is greenish gray to light olive, slightly silty, soft, and calcareous near the base. The Panoba Shale has also been measured at Uch Bazaar and Tarkhobi and is partly exposed in the cores of eroded anticlines at the Mami Khel, Sumari Payan, Shekhan Nala, and Chilli Bagh sections (pls. 2, 3). The formation differs in thickness from section to section and has a maximum thickness of 525 feet at Uch Bazaar. In places, the shale contains thin arenaceous limestone beds and brownish-gray medium-grained calcareous sandstone. Early Eocene Foraminifera have been identified (E. B. Fritz, U.S. Geol. Survey, written commun., 1964).

The Panoba Shale is correlated with the lower two-thirds of the lower Eocene Sakesar Limestone that crops out to the south in the Surghar Range (pl. 3 ) ; this indicates a lateral facies change from shale to limestone. Between the Panoba Shale outcrops in the north and the Sakesar Limestone in the south, however, is a belt of outcrops in which gypsum overlies rock salt. The partly exposed rock salt occupies the cores of eroded anticlines in the same stratigraphic position as the Panoba Shale to the north. This suggests that the rock salt in part is a lateral facies of the Panoba Shale; this facies relationship is described under the heading "Bahadur Khel Salt and Jatta Gypsum."

The top of the Panoba Shale is conformable with overlying Eocene beds except on the west side of the quadrangle (pl. 2). 


\section{SHEKHAN LIMESTONE}

The Shekhan Limestone was named by Davies (1926, p. 207) for outcrops in Shekhan Nala, just east of the town of Kohat. In 1952, Eames (p. 167, 169) subdivided the Shekhan Limestone into four units: Lower Shekhan Limestone, Middle Shekhan Limestone, Upper Shekhan Limestone, and Gypsiferous Beds. These subdivisions were not recognized by the authors in the regional geologic mapping.

At the type section in Shekhan Nala, the Shekhan Limestone is 177 feet thick and is composed of yellowish-gray to gray, massive to thin-bedded nodular limestone, except for the uppermost 30 feet which is gypsiferous shale. The Shekhan Limestone has been measured also in the Panoba and Mami Khel sections; an incomplete section was measured at Tarkhobi, and the formation is exposed at the base of the South Gumbat section (pls. 2-4). At the Tarkhobi section, the upper 204 feet of the formation was measured, where it is composed of interbedded gray limestone and gray, yellowish-gray, or greenish-gray shale. At the Panoba section, the Shekhan Limestone is 235 feet thick. The lowest 90 feet consists of limestone containing shale partings. The next higher 50 feet consists of dusky-yellow fossiliferous shale, and the uppermost 95 feet is limestone containing thin layers of gypsum 30 feet below the top. The limestone is yellowish gray to gray, dense, thin bedded to massive, nodular, argillaceous, and contains abundant Foraminifera.

At the South Gumbat section, only the upper part of the Shekhan Limestone is exposed, where it is composed of yellow and green gypsiferous shale and gypsum. At Mami Khel, the Shekhan Limestone is overlain by a thick bed of gypsum (refer to description of Jatta Gypsum). The upper part of the Shekhan Limestone at Mami Khel is composed of yellow and greenish-yellow shale similar in appearance to that found in the middle of the formation at Panoba (pl. 4). The lower part of the formation is light-gray finely crystalline limestone that is hard, massive, and foraminiferal.

The Shekhan Limestone is correlated with the upper third of the Sakesar Limestone in the Surghar Range (pl. 3). The formation pinches out northwestward and is not found in the Chilli Bagh, Sumari Payan, and Uch Bazaar sections (pl. 3).

Early Eocene Foraminifera have been identified from samples of the Shekhan Limestone (E. B. Fritz, oral commun., 1963). The upper contact of the formation is conformable with overlying Eocene beds.

\section{BAHADUR KHEL SALT AND JATTA GYPSUM}

Large deposits of rock salt and gypsum in the Kohat quadrangle, Gee's $(1945$, p. 305) Kohat Saline Series, seem to be lateral facies of the Panoba Shale and Shekhan Limestone, respectively.

The rock salt is named the Bahadur Khel Salt from exposures in the Bahadur Khel salt quarry (lat $33^{\circ} 09^{\prime} 54^{\prime \prime}$ N., long $70^{\circ} 59^{\prime} 53^{\prime \prime} \mathrm{E}$.), about 51 miles south of the town of Kohat. This is just west of the Kohat quadrangle. The gypsum is named the Jatta Gypsum from exposures in the Jatta salt quarry (lat $33^{\circ} 18^{\prime} 34^{\prime \prime}$ N., long $71^{\circ} 17^{\prime} 30^{\prime \prime}$ E.), about 26 miles south-southwest of the town of Kohat in the Kohat quadrangle.

In the northern belt of Eocene rock outcrops in the Panoba, Tarkhobi, and Shekhan Nala sections, the Panoba Shale and overlying Shekhan Limestone crop out in the cores of eroded anticlines. South of this area, at the Jatta and Bahadur Khel salt quarries, the cores of eroded anticlines are occupied by the Bahadur Khel Salt, which is overlain by the Jatta Gypsum. The Mami Khel Clay overlies the Shekhan Limestone in the north and the Jatta Gypsum in the south (pl. 4).

The Mami Khel section, between the northern and southern outcrops described above is unique in that it contains 140 feet of Jatta Gypsum overlying 86 feet of limestone and shale of the Shekhan Limestone The Jatta Gypsum is overlain by the Mami Khel Clay, and the Shekhan Limestone is underlain by the Panoba Shale (pl. 4). This suggests that the equivalent of the Shekhan Limestone to the south is gypsum. At Jatta, no Shekhan Limestone is found, and the Jatta Gypsum is underlain by the Bahadur Khel Salt. The position of the Bahadur Khel Salt under the Jatta Gypsum at Jatta suggests that the salt may be a facies of the Panoba Shale (pl. 3). The base of the Bahadur Khel Salt in most places is not exposed. During fieldwork near Khumari on the west side of the Kohat quadrangle, an outcrop was found in which a thin bed of Jatta Gypsum is underlain by a thin bed of Bahadur Khel Salt, which is in turn underlain by the Panoba Shale (Meissner and others, 1973). This sequence is overlain by the Mami Khel Clay. This outcrop reveals that where the Bahadur Khel Salt is thin, a considerable thickness of Panoba Shale is found below it. However, at Bahadur Khel, where 1,590 feet of the rock salt was penetrated by drilling (Meissner and others, 1973), this thickness may possibly represent at least a part of Panoba Shale equivalent.

The Jatta Gypsum has greenish-white to gray 
layers and is bedded to massive and hard. It has thin red, purple, and green clay partings and weathers to gray. Thicknesses range from a few feet to 140 feet or more. The Bahadur Khel Salt has a maximum exposed thickness of 320 feet. It is white with a black tinge, bedded to massive, and contains some clear salt crystals.

The upper contact of the Bahadur Khel Salt with the Jatta Gypsum is conformable. The upper contact of the Jatta Gypsum with the Mami Kehl Clay is also conformable.

\section{CHHARAT GROUP}

\section{MAMI KHEL CLAY}

The name Mami Khel Clay was proposed by the authors on the basis of field observations. The type locality is the Mami Khel section, about 2 miles north of Mami Khel village (fig. 3). The Stratigraphic Committee of Pakistan (1964b) in April 1964 accepted the formal name Mami Khel Clay to include the Crimson Clays, Planorbis Beds, Chalky Dolomite, and Ostrea Alternations of Eames (1952, p. 167-168). The committee, furthermore, created the name Chharat Group, which includes the Mami Khel Clay and the overlying Kohat Formation.

At the type locality, the Mami Khel Clay is 406 feet thick and consists of clay which is brownish red to red, soft, silty, and calcareous. It contains thin beds of mottled purple, yellow, and white sandstone near its top. No fossils were found in samples taken at this section, but early Eocene Foraminifera, Gaudryina spp., Eponides spp., Cibicides spp., and Lockhartia spp. (hunti?) were found in samples taken from the same formation in the Chilli Bagh section, 16 miles north of Mami Khel.

The Mami Khel Clay differs in thickness, and a little in lithology, from section to section. Plates 2-4 show that these thicknesses change from 54 feet at Panoba to 406 feet at Mami Khel. To the west, at the Uch Bazaar section, the Mami Khel Clay is absent (pls. 2 and 3). In addition to sandstone, the formation in places contains thin beds of limestone and conglomerate lenses.

The Mami Khel Clay was not recognized by Walter Danilchik and S. M. I. Shah (unpub. data, 1965) in the Surghar Range, and its absence there is probably the result of erosion rather than nondeposition (pl. 3). According to Danilchik (oral commun., 1965), red clay resembling the Mami Khel Clay is found in protected depressions and pockets elsewhere along the Surghar Range.

The upper contact of the Mami Khel Clay is conformable with the overlying Kohat Formation.

\section{KOHAT FORMATION}

The authors proposed the name Kohat Limestone for the predominantly limestone sequence overlying the Mami Khel Clay in the Kohat quadrangle. This sequence is the uppermost Eocene formation in the quadrangle. However, the Stratigraphic Committee of Pakistan (1964b) in April 1964 decided to adopt the formal name Kohat Formation for this sequence because the unit becomes mostly shale to the east, in the Campbellpore quadrangle. The Kohat Formation, as defined by the Committee, is the upper formation of the Chharat Group and is composed of three members :

1. The lower member, the Kaladhand Member, includes the Kohat shales of Davies (1926) and the three subdivisions of the Kohat shales.

2. It is herein proposed to name the middle member the Sadkal Member, from exposures (lat $33^{\circ} 35^{\prime}$ N., long $72^{\circ} 37^{\prime}$ E.) near the community of Sadkal, 1 mile northwest of the village of Fatehjang in the Campbellpore quadrangle, east of the Kohat quadrangle. This member includes the Nummulitic shales of Pinfold (1918, p. 151).

It is difficult to identify the Sadkal Member in the field; the member is easily recognized only in the northeastern part of the Kohat quadrangle where it is a shale. Elsewhere in the quadrangle it is limestone and may generally be recognized only where localities are found containing very large number of Nummulites.

3. The upper member is named the Habib Rahi Limestone Member. This name has recently been designated by the Stratigraphic Committee of Pakistan (1964b) to replace the name Kohat Limestone of Davies (1940, p. 202; 1943). As defined by the Committee in the April 1964 meeting, the Habib Rahi Limestone Member is traceable from the Kohat quadrangle to Rakhi Nala in Waziristan, and from there to the Sui area.

A typical measured exposure of the Kohat Formation is the South Gumbat section, 6.5 miles southwest of the village of Gumbat, which is about midway on the Kohat-Khushalgarh Highway in the eastcentral part of the quadrangle. At this section, the Kaladhand Member is 300 feet thick and is composed of light-gray limestone which is medium to coarsely crystalline, hard, compact, and thin bedded. The limestone contains thin shale beds, especially in the 
lower part. Abundant Foraminifera are present, including the diagnostic early Eocene fossils Orbitolites complanatus, Alveolina oblonga(?), Linderina burgesi, and Assilina pustulosa. The Kaladhand Member in this section is cliff-forming, but in places where it contains more shale beds, it forms a steep slope. The Habib Rahi Limestone Member at South Gumbat is 290 feet thick and is composed of creamcolored, or very light yellowish-brown, and in places pink, limestone, which is coarsely crystalline, hard, compact, and thick bedded to massive. The upper 10 feet is shattered and brecciated. It contains early Eocene Foraminifera. The member forms ridges throughout the belt of Eocene rocks in the Kohat quadrangle.

The Kaladhand Member becomes more massive from east to west in the Kohat quadrangle; on the west side the Kaladhand and Habib Rahi Limestone Members are similar. This is true at the Uch Bazaar section, where the basal 150 feet of the Kaladhand Member is thin bedded and the remaining approximately $\mathbf{3 0 0}$ feet is massive. The main distinguishing feature is the light-brown to cream coloration of the Habib Rahi.

The Habib Rahi is quite consistent in lithology from place to place but ranges in thickness from 50 feet in the Chashanna Ghunda section to 510 feet in the Sumari Payan section.

The Kohat Formation is absent in the Surghar Range (pl. 3) where, if it was deposited, it has been completely eroded away.

The Sirki Shale was the name given by Eames (1952, p. 168) to a small 15-foot-thick exposure of Eocene shale overlying the Kohat Formation near Sirki Paila (lat $33^{\circ} 27^{\prime}$ N., long $71^{\circ} 3^{\prime}$ E.). The shale is brown and contains beds of impure limestone. This shale development is seen only in the vicinity of Sirki Paila and is impractical to map regionally.

The upper contact of the Kohat Formation is unconformable with the overlying Miocene Murree Formation. There is generally a thin conglomerate bed at this contact which is composed of pebbles of limestone of the Kohat Formation in a matrix of sandstone of the Murree Formation. In places a bed of ball-like concretions is just above the top of the Kohat Formation.

\section{MIOCENE SERIES \\ RAWALPINDI GROUP}

The Stratigraphic Committee of Pakistan (1964b) created the formal name Rawalpindi Group. This group is of Miocene age and comprises the Murree Formation and the overlying Kamlial Formation.

\section{MURREE FORMATION}

The Murree series was first named and mapped by Wynne $\left(1874\right.$, p. 66 ) at Murree (lat $33^{\circ} 54^{\prime}$ N., long $73^{\circ} 27^{\prime}$ E.) in Rawalpindi District. The first use of the term "formation" rather than the term "series" to identify these rocks is unknown, but Murree Formation has been accepted by the Stratigraphic Committee of Pakistan as the formal name.

The Murree Formation is composed of sandstone, siltstone, and shale and generally has a high percentage of sandstone and siltstone. The sandstone is dark grayish brown, greenish gray, and in places purple; it is medium to coarse grained or conglomeratic. The shale is purple or reddish brown. Thick sections are found in the northeastern part of the Kohat quadrangle in the vicinity of Cherat, but at Banda Daud Shah, in the southwest, the formation is possibly a maximum of $\mathbf{3 0}$ feet thick.

The Murree Formation was measured at Banda Daud Shah and Hukni (pl. 5). It increases in thickness from about 30 feet at Banda Daud Shah to 640 feet at Hukni (pl. 5).

Correlation of the Murree Formation southward to the Surghar Range is not clear (pl. 3). There are no rocks in the Kohat quadrangle that seem equivalent to the Oligocene Mitha Khatak Formation, named by Walter Danilchik and S. M. I. Shah (unpub. data, 1965) from outcrops in Mitha Khatak Gorge. The Murree Formation is not found above the Mitha Khatak, and it apparently was never deposited.

The Murree Formation is conformable with the overlying Kamlial Formation.

\section{RAMLIAL FORMATION}

The Kamlial Formation was originally named the Kamlial stage by Pinfold $(1918$, p. 154) for rocks at Kamlial (lat $33^{\circ} 17^{\prime}$ N., long $72^{\circ} 35^{\prime}$ E.). Lewis $(1937$, p. 200$)$ referred to the same rocks as the Kamlial Formation. The formal name Kamlial Formation was accepted by the Stratigraphic Committee of Pakistan (1964a) in February 1964.

At Banda Daud Shah in the Kohat quadrangle, the Kamlial Formation is 1,725 feet thick and at Hukni, 23 miles to the east, it is 2,005 feet thick (pl. 5). Three units are recognized at the two sections, but all three are not known to exist throughout the quadrangle. The bottom unit is about 600 feet thick and is composed of sandstone which is mostly greenish gray but in places is gray. It is medium grained, has abundant mica and dark mineral grains, is crossbedded, and contains conglomerate lenses. Sandstone 
layers are as much as $\mathbf{2 5 0}$ feet thick. The sandstone contains a few beds of brownish-red and purple silty clay. The middle unit is also about 600 feet thick and is composed of interbedded sandstone, silty clay, siltstone, and claystone. The sandstone is light gray, fine to coarse grained, and contains conglomerate lenses. It also contains abundant mica flakes and dark mineral grains. This unit forms hogback ridges as much as 100 feet high. The silty clay, siltstone, and claystone are reddish brown and nodular. The top unit is about 500 feet thick at Banda Daud Shah and about 800 feet thick at Hukni. It is composed of sandstone, which is greenish gray to grayish green or light gray, medium to coarse grained, and crossbedded. It contains conglomerate lenses and scattered pebbles. The top unit also is micaceous and contains abundant dark mineral grains. Clay beds in the unit are mottled brown, gray, and green. The sandstone forms hogback ridges as much as 250 feet high.

At Banda Daud Shah, a $10^{\circ}$ angular discordance was observed between the topmost beds of the Kamlial Formation and the basal beds of the overlying Chinji Formation. A conglomerate bed 4 feet thick is found just above this contact in the base of the Chinji Formation. Evidence for this unconformity has not been seen at Hukni; in the Surghar Range to the south, however, an unconformity is likely. In the Chichali Gorge, which bisects the Surghar Range a few miles east of the section shown on plate 3, a zone at the base of the Chinji Formation contains pieces of what may be sandstone of the Kamlial Formation. This may be part of the eroded and redeposited debris of at least a partial section of the Kamlial Formation. The unconformity seems more certain at the top of the Kamlial at Banda Daud Shah, and erosion prior to deposition of the Chinji Formation apparently progressed farther in the Surghar Range than in the Kohat region to the north.

\section{PLIOCENE SERIES SIWALIK GROUP}

The Stratigraphic Committee of Pakistan (1964b) adopted the name Siwalik Group and defined it to include the Chinji Formation as the lowermost unit, the Nagri Formation as the middle unit, and the Dhok Pathan Formation as the top unit.

\section{CHIN JI FORMATION}

The Chinji Formation was originally named the Chinji stage by Pilgrim $(1913$, p. 267) for the type section at the village of Chinji in the Salt Range.
Lewis (1937, p. 200) referred to the same rocks as the Chinji Formation.

The Chinji Formation is described in four units at the Banda Daud Shah section. In the Hukni section, three of these units can be seen, but the uppermost one is apparently absent. The bottom unit is nearly 1,300 feet thick at Banda Daud Shah and more than 1,000 feet thick at Hukni. It consists of interbedded sandstone, silty clay, and siltstone. The sandstone is gray or brownish gray, is crossbedded, and is made up of grains ranging in size from fine to very coarse. It weathers into large spheroidal pieces. Continuous sandstone layers are less than 100 feet thick. The silty clay is either brown or grayish red, or in places is purple and nodular. The siltstone is brownish gray and is interbedded with laminated silty clay. The sandstone beds of the Chinji Formation erode easily, and the formation is typically a valley or slope former.

Above this unit is another about 850 feet thick at Banda Daud Shah and 950 feet thick at Hukni, composed of sandstone containing beds of siltstone and silty clay less numerous than in the unit below. The sandstone is grayish yellow at the base and "salt and pepper" at the top. Grain size is fine to coarse, and the sandstone is less crossbedded than that in the underlying unit. It contains conglomerate beds and abundant black, green, and red mineral grains, and it weathers into reddish-brown rubbly material. The silty clay is red or brownish red and nodular, and the siltstone is laminated and colored like the sandstone. At Banda Daud Shah, about 200 feet above the base of this unit or about 1,500 feet above the base of the formation, bone fragments and a lower jaw complete with teeth were found and later identified by D. H. Dunkle (Smithsonian Inst. oral commun., 1963) as the remains of the mastodon Tetralophodon falconeri. This species lived exclusively during Pliocene time, and this find established the age of the Chinji Formation, at this point in the section.

The next higher unit in the Chinji Formation is about 600 feet thick at Banda Daud Shah and is 700 feet thick at Hukni, where it is the uppermost unit. Like the unit below, it is sandstone, siltstone, and silty clay, but it has recognizable distinguishing features. The sandstone is gray and brownish gray and has rare "salt and pepper" beds. The fine to coarse grain size is like that of the unit below, but the beds are lenticular and made up of 1-inch layers in long sweeping crossbeds. The siltstone is brownish gray, and the silty clay is brownish red.

The topmost unit at Banda Daud Shah, which is apparently absent at Hukni, is mostly silty clay and 
claystone containing yellowish-gray medium- to coarse-grained sandstone at the base. Pale-grayishred to mottled-grayish-brown and olive silty clay and claystone are interbedded with pale-yellowish-brown argillaceous siltstone.

\section{NAGRI FORMATION}

The Nagri Formation was originally named the Nagri stage by Pilgrim $(1913$, p. $267,318,321)$ from rocks near the village of Nagri (lat $32^{\circ} 40^{\prime} \mathrm{N}$., long $72^{\circ} 14^{\prime}$ E.). Lewis $(1937$, p. 199$)$ refers to these same rocks as the Nagri Formation. The Stratigraphic Committee of Pakistan has accepted the name Nagri Formation for the middle formation of the Siwalik Group. Four units of the Nagri Formation have been recognized at the Totaki section and three units, at the Hukni section, but none of the units could be correlated between the two sections (pl. 5).

At Totaki, the Nagri Formation is 12,675 feet thick, which at first seemed excessive to the authors as compared with the 4,834 feet exposed at the Hukni section. A careful check was made to determine whether the Totaki section was repeated by folding or faulting, but no evidence of either was found.

The basal unit of the Nagri Formation at Totaki is 4,305 feet thick and consists of alternating sandstone and clay; sandstone is predominant. The sandstone is light gray, "salt and pepper," brownish gray and greenish gray. It is fine to coarse grained, crossbedded, and at places is highly jointed. Weathering along the joints in sandstone ridges produces a "brick wall" appearance, and, upon disintegration of the ridges by weathering, the sandstone breaks into rounded blocks. Continuous sandstone layers range from 5 to more than 300 feet in thickness but commonly are 50 to 100 feet thick. The steeply dipping sandstone forms hogback ridges. The next higher unit is 4,810 feet of very light gray or gray sandstone and clay. The sandstone is medium to coarse grained, crossbedded, and jointed. The beds are 5 to 180 feet thick and form low ridges. The clay is dark brownish red to grayish red, silty, and has nodular layers. The next higher unit is 3,145 feet of interbedded clay and sandstone, clay being more abundant than sandstone. The clay is brown, grayish red, or orange. It is silty and contains hard layers. The sandstone is light gray or brownish red, sometimes greenish. It is fine to coarse grained, and beds range in thickness from 5 to 300 feet. The sandstone contains conglomerate lenses. About 300 feet above the base of this unit is an ash-colored bed made up of muscovite flakes. The uppermost unit is 415 feet thick, and its top is in fault contact with Eocene rocks. It is predominantly light-gray fine-grained crossbedded sandstone. Beds are 20 to 100 feet thick and form low ridges. Interbedded clay is silty, grayish red and weathers to brownish red.

At Hukni the lowermost unit is mostly sandstone, gray, "salt and pepper," coarse grained, and conglomeratic. Beds range in thickness from 50 to 300 feet. The sandstone is interbedded with grayishbrown, reddish-brown, yellowish-brown silty clay, which is partly nodular. The next higher unit is 2,454 feet thick and consists of interbedded sandstone and clay. The sandstone is greenish gray and gray, or in places, "salt and pepper," and has the "brick wall" appearance found at Totaki. It is crossbedded and contains lenses of conglomerate. Beds range in thickness from 50 to 300 feet and form cliffs and ridges. The beds of clay are like those of the lowermost unit. The top unit is 545 feet thick and is composed of sandstone and clay. At its base is a conglomerate and cobble bed about 40 feet thick. The sandstone is greenish gray, and the clay is red, reddish brown, and yellow. At Hukni, the top of the Nagri Formation is placed at the base of a thick conglomerate sequence of cobble beds of the Dhok Pathan Formation. The cobbles are mostly metamorphic and igneous rocks in a sandy matrix.

The Nagri Formation in the Surghar Range to the south (originally called the Dangot sandstone) is about 6,600 feet thick and is mostly sandstone unlike the sandstone and shale of the Totaki and Hukni sections. On the north flank of the Surghar Range, just north of the southern border of the Kohat quadrangle, the north-dipping Nagri Formation sandstone forms a high jagged mountain front.

\section{DHOK PATHAN FORMATION}

The Dhok Pathan stage was named by Pilgrim $(1913$, p. 278,307$)$ after a village in the Soan River (lat $33^{\circ} 7^{\prime}$ N., long $72^{\circ} 14^{\prime}$ E.), east of the Kohat quadrangle. Lewis (1937, p. 198) referred to these same rocks as the Dhok Pathan Formation, and the Stratigraphic Committee of Pakistan has accepted Lewis' name as the formal name for this formation, the uppermost one of the Siwalik Group.

The Dhok Pathan Formation was not measured but has an estimated exposed thickness of 5,500 feet on the north flank of an anticline approximately 6 miles southeast of the Totaki section (lat $33^{\circ} 07^{\prime} \mathrm{N}$., long $71^{\circ} 09^{\prime}$ E.). The lower 2,400 feet of exposed rocks in the north flank of this anticline consists mostly of sandstone which is light gray, "salt and pepper," coarse grained, and soft. The sandstone is 
very micaceous and contains conglomerate lenses. The upper 3,100 feet of exposed rocks consists of about 70 percent sandstone and 30 percent clay. The sandstone is light gray, coarse grained, and soft. The clay is light reddish brown or gray. The uppermost beds of the Dhok Pathan Formation contain more beds of conglomerate than the underlying beds.

At the Hukni section, the base of the Dhok Pathan Formation consists entirely of igneous and metamorphic cobbles which are bedded conformably with the underlying Nagri Formation and the overlying sandstone and clay beds of the Dhok Pathan Formation.

Just north of Jhamat, on the north flank of the Jhamat anticline (lat $33^{\circ} 18^{\prime}$ N., long $71^{\circ} 55^{\prime}$ E.), cobble beds are interbedded with soft, white sandstone and orange clay similar to that of the Dhok Pathan Formation in the eastern part of the Kohat quadrangle.

No formation younger than the Dhok Pathan Formation has been studied, although many parts of the quadrangle are covered with surficial materials.

\section{MEASURED SECTIONS}

Fourteen outcrop sections were measured, sampled, and described by the authors; two sections were measured earlier by Rizvi and Khan (1955) ; and one section was adapted from a description by Eames (1952). The Kohat Pass road section was sampled in detail but could not be measured because of complex folds and faults. All sections studied are described separately below. All fossil identifications were by E. B. Fritz, formerly of the U.S. Geological Survey. Where diagnostic fossils were not found in the samples, age classifications made by earlier workers in the Kohat District have been used.

\section{UCH BAZAAR}

[The Uch Bazaar section (lat $33^{\circ} 33^{\prime}$ N., long $71^{\circ} 03^{\prime} 30^{\prime \prime}$ E.) is just south of the village of Uch Bazaar and 2 miles north of the village of Hangu (pls 2, 3). The section was measured and sampled during the period October 31-November 3, 1961, by C. R. Meissner, J. M. Master, M. A. Rashid, and Muzaffar Hussain ]

Muree Formation (Miocene) :

Thickness (feet)

Unit L. Sandstone, brownish-gray to gray, fineto medium-grained; 6-inch conglomerate bed at the base, matrix composed of calcareous Murree Formation and grit containing pieces of Murree Formation and underlying Kohat Formation limestone. Early Eocene detrital fossils: Dictyoconus spp., Miliolidae, Orbitolites complanatus, Alveolina elliptica__._Not measured Unconformity (angularity $17^{\circ}$ ).
Kohat Formation (Eocene) :

Habib Rahi Limestone Member:

Unit K. Limestone, light-brown to cream, massive except for top 20 feet, aphanitic, hard. Top highly fossiliferous. Samples K22 and K21 yielded early Eocene fossils: Dictyoconus spp., Miliolidae, Orbitolites complanatus, Alveolina elliptica, Alveolina spp. (crushed). Moderately fossiliferous at bottom. Forms cliffs

Sadkal Member and Kaladhand Member

Unit J. Limestone, gray, aphanitic to finely crystalline, massive, hard, fossiliferous. Sample J20 yielded early Eocene fossils: Dictyoconus spp., Alveolina spp. (crushed), Asterigerina rotula -..-----

Unit I. Limestone, dark-gray to brownishgray, finely crystalline, massive, hard. Contains abundant large early Eocene. Foraminifera: Samples I19, I18, and I17 yielded: Orbitolites, Alveolina spp., Dictyoconus spp., Asterigerina rotula, Lockhartia hunti, Linderina brugesi, Nummulites spp., Dictyoconoides vredenburgi, Nummulites biharyensis, N. mamilla? Assilina granulosa, A. pustulosa ------

Unit H. Limestone, mottled gray and brown, irregular earthy appearance, thin-bedded (6 in. or less). Highly fossiliferous; lower Eocene. Sample H16 yielded Alveolina elliptica? Flosculina globosa, Asterigerina rotula, Nummulites mamilla, Assilina aff. A. sub-

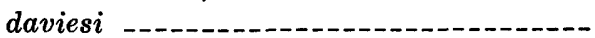

Unit G. Covered interval -..

Unit F. Limestone, gray with brown specks aphanitic, interbedded thick and thin beds; early Eocene fossils. Samples F15 and F14 yielded: Dictyoconus, Miliolidae, Alveolina oblonga, Dictyoconoides vredenburgi

Unconformity (?).

Panoba Shale (Eocene) :

Unit E. Shale, grayish-green to brownishgreen, soft, loose, in places silty and calcareous. At 532 feet from the top is a thinbedded arenaceous brownish-gray limestone containing layers of soft brownish-gray marl. At the top is a sticky red calcareous clay interbedded with brownish-green shale. Forms slope and valley. Early Eocene fossils. Samples E9, E11, E12, and E13, yielded Eponides spp., Cibicides spp., Globorotalia aequa, $G$. aff. G. whitei, Nummulites spp., Assilina

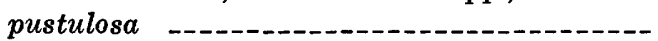

Contact not seen.

Patala Formation (Paleocene and Eocene) :

Not exposed. This zone should contain upper Paleocene and lower Eocene shales
Thickness (feet)

161

140

60

50 


\section{Thickness \\ (feet)}

Lockhart Limestone (Paleocene) :

Unit D. Limestone, dark-gray to black, finely crystalline hard, massive. Two sets of joints give blocky appearance on the cliff face. Weathers into rounded nodules, surface looks "brecciated." Fetid odor. Fossiliferous; Paleocene. Sample D6 yielded Lockhartia hunti, Miscellanea spp.

Hangu Formation (Paleocene) :

Unit C. Sandstone, white, weathers to rustbrown, medium-grained, rounded quartz grains, contains small iron nodules; crossbedded; siliceous cement. Lenses of conglomerate composed of quartz and chert pebbles ranging in size from $1 \frac{1 / 4}{4}$ to $1 / 2$ inches .....

Unconformity; contact sharp; iron concretions.

Darsamand Limestone (Cretaceous) :

Unit B. Limestone, brownish-gray to cream, finely crystalline, hard; no fossils seen; forms cliff

Unit A. Limestone (incomplete section), gray, finely crystalline, hard, massive; forms cliff; fossiliferous; Upper Cretaceous. Samples A1 and A2 yielded Globotruncana spp

,

\section{MAMI KHEL}

[The Mami Khel section (lat 33०22'05" N., long $71^{\circ} 11^{\prime} 58^{\prime \prime}$ E.) is $11 /$ miles northeast of the village of Mami Khel (pls. 3, 4). The section was measured and sampled during the period November 6-9, 1961, by J. M. Master, C. R. Meissner, Muzaffar Hussain, and M. A. Rashid]

Murree Formation (Miocene) :

Unit A. Sandstone, light- to dark-brownish-red, gray tinge, fine- to coarse-grained, hard; conglomerate 3 feet thick at base has cobbles of Kohat Formation limestone as large as 9 inches in a matrix of Murree gravel. Early Eocene(?) reworked fossils: Orbitolites, Alveolina oblonga?, Linderina brugesi, Lockhartia? spp., Nummulites aff. N. mamilla _._. Not measured

Unconformity.

Kohat Formation (Eocene).

Habib Rahi Limestone Member:

Unit B. Limestone, cream to dark-gray weathers to brown, finely crystalline, hard massive; forms cliff. Early Eocene fossils; sample B3 yielded Dictyoconus spp., Miliolidae, Orbitolites complanatus, Alveolina

Sadkal Member and Kaladhand Member:

Unit C. Limestone, gray to olive-gray, surface brown, finely crystalline, nodular appearance; lower bed silty and shaly; forms slope. Early Eocene fossils; samples C5 and C6 yielded Dictyoconus spp., Miliolidae, Orbitolites complanatus, Alveolina spp., Globogerina, Dictyconoides vredenburgi?

Kohat Formation-Continued

Thickness

(feet)

Sadkal Member and Kalahand Member-Continued

Unit D. Shaly limestone, olive-gray to gray, finely crystalline, hard, thin-bedded; lower beds shaly and silty. Early Eocene fossils; samples D7 and D8 yielded Dictyoconus spp., Miliolidae, Orbitolites complanatus, Cibicides spp., Lockhartia hunti, Ostracoda

Unit E. Limestone, dark-gray to medium gray, finely crystalline, thin-bedded. Early Eocene fossils; sample E9 yielded Dictyoconus spp., Miliolidae, Orbitolites, Alveolina spp., Lockhartia hunti -...--

Unit F. Top is silty sandstone, brownishgray, thin-bedded, calcareous, highly fossiliferous; at top about 12 feet of silty shale, greenish-brown, yellowweathering, soft, calcareous, very thinbedded. Lower two-thirds sandstone, medium-gray, fine-grained, hard, calcareous, thin-bedded, has silty bands; forms ridge. Early Eocene fossils; samples F11 and F12 yielded Dictyoconus spp., Miliolidae, Alveolina spp., Dictyoconoides vredenburgi

Unit G. Limestone, brownish-gray, medium-gray, medium-crystalline, thinbedded. Fossiliferous (nondiagnostic) ---

Unit H. Covered interval

Mami Khel Clay (Eocene) :

Unit I. Limestone; upper part white, chalky, massive; lower part dark-gray, finely crystalline, massive

Unit J. Clay, brownish-red to red, soft silty, calcareous. About 40 feet from the top are two thin ( $5 \mathrm{ft} \pm$ ) sandstone beds interbedded with red clay; the upper bed is stained purple, the lower one red. Forms valley and slope. No fossils seen; two samples (J17 and J18) barren.

Jatta Gypsum (Eocene) :

Unit K. Gypsum, greenish-white to gray; partings of red and purple clayey material in upper beds; weathers to gray; thin-bedded, banded, hard, compact; lower part brown, crystalline, massive, hard; unfossiliferous -Shekhan Limestone (Eocene) :

Unit L. Shale, greenish-yellow to yellow, soft, thin-bedded, calcareous; iron-stained brown in places. Early Eocene fossils; samples L23 and L24 yielded Nonion micra (two specimens), Globorotalia aequa, Globorotalia aff. G. aragonensis _................... Covered interval

Unit M. Limestone, light-gray, finely crystalline to aphanitic, hard, massive; forms ridge. Highly fossiliferous, lower Eocene; sample M25 yielded: Orbitolites complanatus fragments, Alveolina spp., Flosculina globosa, Globorotalia spp _....... 
Panoba Shale (Eocene) :

Unit N. Shale, greenish-gray, soft, loose (base of section partial exposure). Early Eocene fossils; sample N26 yielded: Eponides spp., Globorotalia quadrata? Not measured

\section{CHILLI BAGH}

[The Chilli Bagh section (lat $33^{\circ} 35^{\prime} 20^{\prime \prime}$ N., long $71^{\circ} 16^{\prime}$ E.) is 1 mile southeast of the Chilli Bagh police station and half a mile south of the Kohat Creek (pls. 2, 3). The section was measured during November 910,1961 , by C. R. Meissner and M. A. Rashid]

Thickness

Muree Formation (Miocene): Covered with talus, contact not visible Not measured

Kohat Formation (Eocene) :

Habib Rahi Limestone Member:

Unit A. Limestone, light-brown, lightgray, cream, in places pink; aphanitic to finely crystalline, hard, thick bedded to massive; shattered; irregular rubbly upper surface; calcite veins. Sparsely fossiliferous, lower Eocene; samples A1, A2, A3, and A4 yielded Dictyoconus spp., Orbitolites mamilla?, Alveolina spp., Flosculina globosa, Asterigerina rotula?, Linderina brugesi ..................

Sadkal Member and Kaladhand Member:

Unit B. Limestone, brownish-gray, finely crystalline, hard; bottom part, dark-gray, soft, flaggy, and thin-bedded. Early Eocene fossils; samples B5 and B6 yielded Dictyoconus spp., Orbitolites complanatus, Asterigerina rotula?, Nummulites spp., Assilina pustulosa

Unit C. Covered interval _......

Unit D. Limestone, brownish-gray, aphanitic, hard, thin-bedded ( $6 \mathrm{ft}$ or less). Sparsely fossiliferous ..............

Unit E. Limestone, brownish-gray to gray, finely crystalline, hard, thin-bedded, interbedded with mottled brown soft calcareous siltstone and fossiliferous silty limestone. Early Eocene fossils; samples E8, E9, E10, E11, E12, and E13 yielded Dictyoconus spp., Cibicides spp., Lockhartia spp., Nummulites sp., Ostracoda, megafossil fragments

Unit F. Shale, mottled, silty, calcareous; soft; abundant early Eocene fossils; samples F14, F14a, and F14b yielded Clavulina spp., Robulus spp., Eponides spp., Cibicides spp., Lockhartia spp., Nummilites spp., Assilina granulosa, A. pustulosa?, Ostracoda

Mami Khel Clay (Eocene) :

Unit G. Dolomite, cream-colored, chalky

Unit H. Clay, brick-red to dull-red, silty and calcareous; contains brownish-gray, gritty, hard, thin-bedded, calcareous, highly fossiliferous sandstone layers: conglomerate lenses at the base contain chert and quartz pebbles as large as 2 inches. Clay has a 1-inch-thick

\section{Thickness
(feet)}

Mami Khel Clay (Eocene)-Continued

Unit $\mathrm{H}$-Continued

band of platy pink, translucent to white, sucrosic gypsum. Early Eocene fossils; samples H16 and H17 yielded Gaudryina spp., Orbitolites complanatus, Eponides spp., Cibicides spp., Lockhartia spp., Nummulites spp., megafossil fragments -...-.....

Unconformity.

Panoba Shale (Eocene) :

Shale, gray, greenish-gray, soft Unmeasured

\section{SOUTH GUMBAT}

[The South Gumbat section (lat $33^{\circ} 26^{\prime} 45^{\prime \prime} \mathrm{N}$, long $71^{\circ} 35^{\prime} \mathrm{E}$.) is 5 miles southwest of the village of Gumbat (pl. 4). The section was measured during the period November 20-22, 1961, by J. M. Master, M. A. Rashid, and Muzaffar Hussain]

Murree Formation (Miocene) :

Thickness (feet)

Unit E. Sandstone, dark brownish-red to purple, hard, fine- to coarse-grained, interbedded with red clay Not measured

Unconformity.

Kohat Formation (Eocene) :

Habib Rahi Limestone Member :

Unit D. Limestone, cream, coarsely crystalline, hard, compact, thick-bedded to massive; has calcite veins in shattered rubbly top; weathered surface brown; ridge-forming. Early Eocene fossils; sample D5 yielded Dictyoconus spp., Miliolidae, Orbitolites complanatus, Alveolina spp

Sadkal Member and Kaladhand Member

Unit C. Limestone, light- to medium-gray, coarsely crystalline, hard, thin-bedded; shale partings, lower part more shaly; forms ridge. Contains abundant early Eocene fossils: samples $\mathrm{C4}$ and $\mathrm{C3}$ yielded Orbitolites complanatus, Alveolina spp., Alveolina oblonga?, Cibicides spp., Linderina brugesi, Nummulites spp -

Mami Khel Clay (Eocene) :

Unit B. Clay, brick-red to dull-red, soft, silty, poorly stratified, calcareous; forms slopes; unfossiliferous (?)

Shekhan Limestone (Eocene) :

Unit A. Shale, yellowish-green, in part yellow, soft to hard; at places contains banded or laminated hard gypsum layers; forms low ridge; unfossiliferous (?) Not measured

\section{SUMARI PAYAN}

[The Sumari Payan section (lat $33^{\circ} 26^{\prime} 30^{\prime \prime}$ N., long $71^{\circ} 18^{\prime}$ E.) is $1 \frac{1 / 2}{2}$ miles southeast of the village of Sumari Payan (pl. 3). The section was measured during the period November 27-29, 1961, by J. M. Master, and Muzaffar Hussain]

Thickness (feet)

Murree Formation (Miocene) :

Unit E. Sandstone, dark-brown, mediumgrained -..... Not measured 
Kohat Formation (Eocene) :

Habib Rahi Limestone Member:

Unit D. Limestone, cream-colored, mediumcrystalline, hard, thick-bedded $\left(2 \frac{1}{2} \mathrm{ft}\right.$ or more); veined with calcite; weathered surface shattered and rubbly; forms ridge. Highly fossiliferous; $10 \mathrm{wer}$ Eocene; sample D4 yielded Dictyoconus spp., Orbitolites complanatus, Alveolina spp., crushed, Nummulites spp -..---.--

Sadkal Member and Kaladhand Member:

Unit C. Limestone, light-gray, mediumcrystalline, hard, has calcite veins; weathered surface gray with black tinge; contains shale partings; thinbedded ( 6 in-2 ft); lower part more shaly than upper part. Highly fossiliferous; lower Eocene; sample C3 yielded Miliolidae, Orbitolites complanatus, Alveolina spp., Flosculina globosa

Mami Khel Clay (Eocene) :

Unit B. Clay, dark-red to dull-red, soft, poorly stratified, weathers to brownish-red; contains a 1-foot-thick dark-red grit zone; unfossiliferous

Unconformity.

Panoba Shale (Eocene):

Unit A. Sandstone bed at the top, brownishgray, medium-gray, medium-grained, hard, thin-bedded ( 6 in-1 ft); calcareous, weathers to dirty brown, underlain by shale, graygreen, soft. Highly fossiliferous; lower Eocene; sample A1 yielded Orbitolites complanatus, Nummulites sp p., megafossil fragments -_-

\section{BANDA DAUD SHAH}

[The Banda Daud Shah section (lat $33^{\circ} 15^{\prime} 30^{\prime \prime}$ N., long $71^{\circ} 11^{\prime} 10^{\prime \prime}$ E.) is approximately 1 mile south-southwest of the village of Banda Daud Shah (pls. 3, 5). The section was measured during the period November 27-December 4, 1961, by C. R. Meissner and M. A. Rashid]

Nagri Formation (Pliocene):

Thickness (feet)

Unit I. Sandstone, greenish-gray, medium- to thick-bedded $(11 / 2-6 \mathrm{ft})$; contains a 7-footthick conglomerate bed 25 feet from the bottom; forms cliffs Not measured

Chinji Formation (Pliocene) :

Unit $H$. Silty clay and claystone, pale-grayish-red to mottled gray-brown and olive, interbedded with pale-yellowish-brown argillaceous siltstone; sandstone at base, yellowishgray, medium- to coarse-grained .......-

Unit G. Sandstone, gray and brownish-gray, rarely "salt and pepper," fine- to coarsegrained, lenticular, thin-bedded (generally 1 in. or less); long, sweeping crossbeds at intervals; contains beds of brownish-gray siltstone, and brownish-red silty clay -..---

Unit F. Sandstone, grayish-yellow at the base, "salt and pepper" at the top; fine- to coarsegrained, less crossbedded than unit E; conglomerate beds; abundant black, green, and
Chinji Formation (Pliocene)-Continued

Thickness

(feet)

Unit F-Continued

red minerals; weathers rubbly; interbedded with reddish-brown nodular silty clay and laminated siltstone. At 615 feet from the top of Unit F, the jawbone, with teeth in place, of a mastodon, Tetralophodon falconeri, was found in a conglomerate bed. Loose pieces of teeth and bone fragments were also found. According to D. H. Dunkle, Smithsonian Institution, this animal lived exclusively in

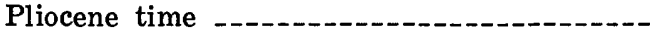

Unit E. Sandstone, gray, brown, fine-grained to conglomeratic, crossbedded, spheroid a l weathering; contains layers of nodular silty clay, brown to grayish-red, in part purple. In lower part(?) siltstone, brownish-gray, interbedded with laminated silty clay .....-Unconformity? (10 ${ }^{\circ}$ angularity).

Kamlial Formation (Miocene) :

Unit D. Sandstone, greenish-gray to grayishgreen, in part light-gray, medium- to coarsegrained, crossbedded; contains pebbles of limestone and sandstone as large as 2 inches; micaceous, has abundant dark-mineral grains, contains conglomerate layers; forms ridges; in part clay, mottled brown, gray, and green.

Unit C. Sandstone, light-gray, fine- to coarsegrained, thin-bedded, includes conglomerate lenses, micaceous, contains abundant darkmineral grains; a few beds are as much as 200 feet thick; forms ridges; in part reddishbrown nodular silty clay, siltstone, and claystone

Unit B. Sandstone, greenish-gray, in part gray, medium-grained, crossbedded, micaceous; has abundant dark-mineral grains; includes conglomerate lenses. At base is a thin $(20 \mathrm{ft}+)$ section of Murree Formation consisting of conglomerate at base, brownish-gray sandstone at top; conglomerate contains Kohat Formation limestone and sandstone pebbles

Unconformity.

Kohat Formation (Eocene) :

Habib Rahi Limestone Member:

Unit A. Limestone, cream-colored, finely crystalline, hard, thick-bedded; shattered irregular surface, rubbly looking. Highly fossiliferous (unidentified). At the contact of the Murree Formation and the Kohat Formation is a salt-water spring -..--

\section{SOUTH LACHI}

[The South Lachi section (lat $33^{\circ} 21^{\prime} 25^{\prime \prime}$ N., long $71^{\circ} 18^{\prime} 38^{\prime \prime}$ E.) is 3 miles southwest of the vilage of Lachi (fig. 3). The section was measured during the period December 4-5, 1961, by J. M. Master and Muzaffar Hussain ]

Thickness

(feet)

Murree Formation (Miocene) :

Unit A. Sandstone, purplish-brown, and red 
Murree Formation (Miocene)-Continued

Unit A-Continued

shale; conglomerate at base; thin beds of very coarse purplish-brown sandstone (4-8 in.). Pebbles of limestone embedded in a sandy matrix Not measured

Unconformity.

Kohat Formation (Eocene) :

Habib Rahi Limestone Member:

Unit B. Limestone, cream-colored mediumcrystalline, thin-bedded ( 6 in-2 ft); lower part more shaly than upper part; forms slope. Highly fossiliferous; lower Eocene; sample B2 yielded Dictyoconus spp., Orbitolites complanatus, Alevolina oblonga

Sadkal Member and Kaladhand Member:

Unit C. Limestone, cream to gray, mediumcrystalline, hard, thin-bedded, (6 in-2 $\mathrm{ft}$ ), shaly; lower part more shaly; forms slope. Highly sosiliferous; $10 \mathrm{wer}$ Eocene; sample C3 yielded Dictyoconus spp., Orbitolites complanatus, Alveolina oblonga

Mami Khel Clay (Eocene) :

Unit D. Clay, dark-red to dull-red, soft, partly stratified weathered surface brownish-red; unfossiliferous (?)

Jatta Gypsum (Eocene) :

Unit E. Gypsum; thickness not stratigraphic. The gypsum forms the core of an anticline and is exposed in repeated sequence for 481 feet from flank to flank. The gypsum is earthy, yellowish green, very thin, evenly bedded, contains green and yellow beds; weathered surface hard and green, contains nondiagnostic fossils

Unit F. Repeated Mami Khel Clay _..._. Not measured

\section{MAZARI TANG}

[The Mazari Tang section (lat $33^{\circ} 45^{\prime}$ N., long $71^{\circ} 56^{\prime} 30^{\prime \prime}$ E.) is 1 mile east-northeast of the village of Mazari Tang ( $\mathrm{pl} \mathrm{2}$ ). The section was measured during the period December $7-9,1961$, by C. R. Meissner and M. A. Rashid]

Cretaceous ( ?) :

Thickness (feet)

Unit Q. Limestone, grayish-brown to brown, crystalline, thin-bedded, chalky_._._._._Not measured

Thrust fault.

Patala Formation (Paleocene and Eocene) :

Unit $P$. Limestone, light- to dark-brownishgray, finely crystalline, hard, medium-bedded (5 ft or less); fetid odor on fresh surface; weathers into square or irregular blocks as large as 5 feet, surface cavernous, pitted, corrugated; forms ridges. Crowded with Paleocene fossils; samples P29 and P30 yielded Miscellanea miscella, M. stampi? -.-

Unit O. Limestone, mottled light-brownish-gray, earthy; argillaceous and silty at bottom; top part, thin-bedded ( $\mathrm{few}$ inches to $2 \mathrm{ft}$ ), hard, nodular, weathered surface earthy; forms
Patala Formation (Paleocene and Eocene)-Continued

Unit $\mathbf{0}$-Continued valley. Highly fossiliferous; Paleocene; samples 027 and 028 yielded Miliolidae, Lockhartia hunti?, Miscellanea miscella, $M$. stampi?

Unit N. Limestone, gray to brownish-gray to dark-gray, finely crystalline to medium-crystalline, hard, medium- to thick-bedded ( 8 in$10 \mathrm{ft}$ ), nodular or seminodular; very faint fetid odor from fresh break; forms cliff. Fossiliferous; Paleocene; samples N24, N25, and N26 yielded Miliolidae, Miscellanea miscella, M. stampi?, Daviesina? spp -......-

Unit M. Limestone, silty, mottled light-brown, yellow, and gray, hard; weathers into nodular and seminodular pieces; forms cliff. Highly fossiliferous; Paleocene; sample M23 yielded Lockhartia hunti, Miscellanea miscella, megafossil fragments

Lockhart Limestone: (Paleocene)

Unit L. Limestone, light-brownish-gray to darkgray, aphanitic to very finely crystalline, very hard, thick-bedded (as much as $16 \mathrm{ft}$ ); has two prominent sets of joints; surface pitted and corrugated; forms cliff. Paleocene fossils; samples L20, L21, and L22 yielded Lockhartia? spp., Miscellanea? spp., Discocyclina spp., Miscellanea miscella, M. stampi? --

Hangu Formation (Paleocene) :

Unit K. Limestone, silty, light-brownish-gray, aphanitic to very finely crystalline, thinbedded, hard, nodular; weathers to earthy brown; forms slope. Contains minute fossil casts; Paleocene fossils; sample K19 yielded Miscellanea miscella, $M$. stampi?

Unit J. Limestone, light-brownish-gray, aphanitic to very finely crystalline, hard, compact, medium-bedded (1-3 ft), nodular to seminodular, faint fetid odor on fresh break; weathers earthy; forms small cliff. Crowded with Paleocene fossils; samples J17 and J18 yielded Lockhartia spp., L. hunti, Miscellanea miscella, M. stampi?

Unit I. Calcareous clay and argillaceous limestone, mottled brown, yeliow, and greenishgray, soft, earthy-looking, thin-bedded (a few inches); has beds of limestone, gray, medium to coarsely crystalline, hard; forms depression. Coral(?) pieces in calcareous clay; Paleocene fossils; samples I15 and I16 yielded Miscellanea miscella

Unit H. Limestone, brownish- to dark-gray, finely to coarsely crystalline, very hard, mediumto thick-bedded $(2-30 \mathrm{ft})$; fetid odor on fresh surface; forms ridge. Paleocene fossils distributed in certain zones; samples H13 and H14 yielded Opertorbitolites douvillei?, Lockhartia hunti, var. pustulosa, Miscellanea miscella

Darsamand Limestone (Cretaceous):

Unit G. Argillaceous limestone, light-gray to 
Darsamand Limestone (Cretaceous)-Continued

Unit G-Continued

gray, dense, hard, thin-bedded (as much as a few inches); weathers into seminodular pieces; outcrop color pale blue, chalky looking; forms slope. Fossils: (top) Paleocene; sample G12 yielded Globorotalia spp., Lockhartia hunti, Miscellanea spp., Kathina spp.; (bottom) Late Cretaceous; sample G11 yielded Globotruncana spp. (double keeled) -Lumshiwal Sandstone (Cretaceous) :

Unit F. Transitional zone: top part sandy limestone, grayish-brown to brown, glauconitic; bottom part sandstone, greenish-gray, calcareous. Late Cretaceous fossils; sample F10 yielded Globigerina spp., Globotruncana

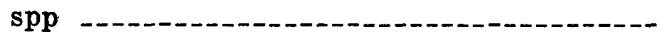

Unit E. Sandstone, greenish-brown, finegrained, hard, thin-bedded and flaggy, slightly calcareous _...........

Unit D. Sandstone, light-brownish-white (laminated brown and white), medium-grained, well-sorted, hard; composed of quartz grains; weathers soft, forms slight ridge -......-.-

Unit C. Sandstone, grayish-brown, fine-grained, thin-bedded (few inches to $1 \mathrm{ft}$ ); weathers to brownish green and has surface the color of malachite

Chichali Formation (Cretaceous) :

Unit B. Sandstone, dark-green, coarse-grained, soft, friable, surface stained yellowish-brown; zones of dark weathered glauconite; many belemnites and ammonites

Unconformity.

Datta Formation (upper member) (Jurassic) :

Unit A. Limestone, brownish-gray to yellowishgray, aphanitic to very finely crystalline, thin-bedded (few inches to $3 \mathrm{ft}$ ); shale partings toward bottom in a pale-red to brownishred thin-bedded zone (4-12 in.) ; outcrop yellowish brown; from distance looks like sandstone. Surface of uppermost bed contains abundant ferruginous belemnites and cephalopods

Thrust fault.

Mami Khel Clay (?) (Eocene):

Clay, greenish-red to red Not measured

\section{JATTA SALT QUARRY}

[The Jatta salt quarry section (lat $33^{\circ} 18^{\prime} 34^{\prime \prime}$ N., long $71^{\circ} 17^{\prime} 30^{\prime \prime}$ E.) is 6 miles southwest of the village of Lachi (pls. 3, 4). The section was measured December 11, 1961, by J. M. Master and Muzaffar Hussain]

Kohat Formation (Eocene) :

Thickness (feet)

Kaladhand Member:

Unit D. Limestone, light-gray, mediumcrystalline, hard; shale partings. Very fossiliferous (nondiagnostic) _..._- Not measured

Mami Khel Clay (Eocene) :

Unit C. Clay, red to dull red, soft; sandstone beds in middle and at base. Nondiagnostic Radiolaria
Jatta Gypsum (Eocene) :

Unit B. Gypsum, green with brown layers, massive; shaly toward base; fossiliferous...

Thicleness

(feet)

(feet)

\section{Chinji}

adur Khel Salt (Eocene) :

Unit A. Rock salt, white with black coloration, massive, transparent at some places _...- Not measured

\section{HUKNI}

[The Hukni section (lat $33^{\circ} 14^{\prime} 30^{\prime \prime}$ N., long $71^{\circ} 35^{\prime} 30^{\prime \prime}$ E.) is 6 miles east of the village of Shakardarra (fig. 3) and 11/2 miles north-northeast of the village of $\mathrm{Jabli}$. The section was measured during the period December 28, 1961-January 1, 1962, by J. M. Master, Muzaffar, Hussain, and M. A. Rashid]

Thicleness (feet)

Dhok Pathan Formation (Pliocene) :

Unit H. Thick boulder beds consisting of 80 percent boulders as much as 9 inches in diameter and 20 percent sand _........ Not measured

Nagri Formation (Pliocene) :

Unit G. Sandstone and clay, interbedded; sandstone, greenish-gray, coarse-grained, beds 20 to 100 feet thick, some layers contain pebbles (4 in. or less) composed of quartz, limestone, and sandstone; 14 feet from the base is a conglomerate with a boulder bed ( 80 percent boulders and pebbles, 20 percent sandstone) ; clay, light-brick-red to reddish-brown, in places yellow, sandy in part, nodular, calcareous

Unit F. Sandstone and clay, interbedded; sandstone, greenish-gray, in part gray, coarsegrained, in part gritty, crossbedded, beds 10 to 250 feet thick, scattered pebbles; conglomerate beds as much as 15 feet thick contain cobbles 2 to 8 inches in diameter; clay, red or reddish-brown and yellow, generally sandy and silty

Unit E. Sandstone and clay, interbedded; sandstone, gray, "salt and pepper," coarsegrained, soft, calcareous, micaceous, beds 10 to 300 feet thick; clay, reddish-brown, in places silty

Unit D. Sandstone, siltstone, and silty clay, interbedded; sandstone, gray to greenish-gray, in places yellowish-green, fine- to coarsegrained, interbedded with siltstone, beds a a few inches to 250 feet thick, a few conglomerate lenses; clay, pink or orange, silty and sandy

Unit C. Sandstone, siltstone, and silty clay, interbedded; sandstone, dark-brown, gray, and "salt and pepper," medium- to coarse-grained to conglomeratic, poorly sorted, beds 10 to 50 feet thick, crossbedded, interbedded with yellowish-gray siltstone and red to brownishred silty clay

Unconformity.

Kamlial Formation (Miocene) :

Unit B. Sandstone, clay, and silty clay, interbedded; sandstone, greenish-gray to gray, 
Kamlial Formation (Miocene)-Continued Unit B-Continued

fine- to coarse-grained, fairly hard to soft, beds 50 to 100 feet thick, crossbedded, weathers into rounded and spheroidal surface, some scattered pebbles and conglomerate lenses; interbedded with reddish-brown silty clay and light- to dark-brownish-red, nodular clay, both containing lenses of brownish-gray to gray sandstone

Unit A. Sandstone and clay, interbedded; sandstone, greenish-gray to gray, fine- to coarsegrained, beds 25 to 250 feet thick, crossbedded, fairly hard, has conglomeratic lenses; interbedded with grayish-red, purple, or brownish-red calcareous, slightly silty clay.-

Murree Formation (Miocene) :

Unit AA. Sandstone, siltstone, and shale, interbedded; sandstone, purple, dark-grayishbrown, or greenish-gray, medium- to coarsegrained to gritty, interbedded with siltstone and purple or reddish-brown shale

Unconformity.

Kohat Formation (Eocene) :

Habib Rahi Limestone Member Not measured

\section{MARAI BALA}

[The Marai Bala section (lat $33^{\circ} 44^{\prime}$ N., long $71^{\circ} 09^{\prime}$ E.) is $2 \frac{1 / 2}{2}$ miles northwest of the village of Marai Bala (pls. 2, 3). The section was measured during the period February 1-3, 1962, by C. R. Meissner and M. A. Rashid]

Lockhart Limestone (Paleocene) :

Thicleness (feet)

Unit A. Limestone, gray with brown tinge, medium-crystalline, $\mathrm{h}$ a $\mathrm{rd}$, thick-bedded, oolitic, forms cliffs. Abundant nondiagnostic fossils in some layers Not measured

Hangu Formation (Paleocene) :

Unit B1. Shale, light-gray, hard, splintery, very calcareous, forms slope. Equivalent to Hangu Sandstone (?)

Transitional zone, calcareous shale and nodular limestone. Late Cretaceous fossils; sample B3 yielded Globotruncana spp ..........

Darsamand Limestone (Cretaceous) :

Unit B2. Limestone, light-gray, hard, nodular, very argillaceous, conchoidal fracture, forms slope. Late Cretaceous fossils; sample B4 yielded Globotruncana spp ..................

Unit B3. Limestone, light- to dark-gray, aphanitic, hard, conchoidal fracture, thin-bedded (3 in-1 ft), has shale partings; weathers into nodules, forms slope. Late Cretaceous fossils; sample B5 yielded Globotruncana spp. (double keeled)

Unit C. Limestone, brown-gray, hard, thickbedded (as much as $10 \mathrm{ft}$ ), breaks into thin sharp plates with metallic sound when struck; base is sandy, glauconitic, contains ironcoated fossil casts (pelecypods, gastropods). Unconformity at base. Late Cretaceous fossils; sample C6 yielded Globotruncana spp. (double keeled) (feet)

Unconformity.

Lumshiwal Sandstone (Cretaceous) :

Unit D. Shale, black, carbonaceous, hard; and sandstone, brown-green, medium, calcareous, glaucontic, soft

Unit E. Sandstone, quartzitic, white, stained brown, fine- to medium-grained; composed of quartz grains, very hard, but top beds softer; beds as much as 6 feet thick, breaks into big blocks along two sets of well-developed joints; concretionary iron band (10 ft thick) about 50 feet from top; forms cliff in part and slope in part

Chichali Formation (Cretaceous) :

Unit F. Covered slope

Thickness

(feet)

Unconformity.

Samana Suk Limestone (Jurassic) :

Unit G. Limestone, dark-gray, brown in places, aphanitic to very finely crystalline, and hard; top beds oolitic, well-jointed, surface pitted. Nondiagnostic megafossils at intervals -..--

Unit H. Limestone, gray, aphanitic, shaly, very thin-bedded (4 in. or less) platy ...-...-.-

Datta Formation (Jurassic) :

Upper member:

Unit I. Limestone, dark- or brownish-gray, has a brown tinge in places on outcrop, aphanitic to finely crystalline; very coarsely crystalline and oolitic in places; beds 1 inch or less to 3 feet thick, thin, platy, splintery layers; thicker beds form small steplike cliffs. Highly fossiliferous zones, Jurassic; samples I18, I19, I20, I21, I22, and I24 yielded a rotaloid, Bolivina spp., and megafossil fragments

Lower member:

Unit J. Limestone, dark-gray (top) to dark-brownish-gray, aphanitic to very finely crystalline, hard and compact, beds a few inches to 5 feet thick, thin platy layers; top more shaly; forms slopes. Bottom contains many fossils; sample J26 yielded nondiagnostic megafossil fragments

Thrust fault.

Paleocene(?) repeated at base of section -_-_Not measured

\section{CHASHANNA GHUNDA}

[The Chashanna Ghunda section (at $33^{\circ} 21^{\prime} 40^{\prime \prime}$ N., long $71^{\circ} 37^{\prime}$ E.) is 1 mile east-southeast of the village of Chashanna Ghunda (fig. 3). The section was measured during the period February 1-3, 1962, by J. M. Master and Muzaffar Hussain]

Thickness (feet)

Murree Formation (Miocene) :

Unit A. Sandstone, dark-purple to red; clay, purple _.... Not measured

Unconformity.

Kohat Formation (Eocene) :

Habib Rahi Limestone Member:

Unit B. Limestone, cream-colored, finely crystalline, compact, rubbly surface. Very fossiliferous; fossils not identi- 
Kohat Formation (Eocene)-Continued

Sadkal Member and Kaladhand Member:

Unit B. Limestone, light- to medium-gray, finely to medium-crystalline, hard; contains thin calcite veins; weathers nodular; shale partings; lower part more shaly. Very fossiliferous; lower Eocene; samples B2 and B3 yielded Alveolina elliptica, Eponides spp., new fauna, Lockhartia hunti?, Ostracoda, Gavelinella spp -_......

Mami Khel Clay (Eocene) :

Unit C. Clay, red to dull-red, poorly stratified, soft, slightly calcareous; contains a grit band 1 foot thick in lower half

Jatta Gypsum (Eocene) :

Unit D. Gypsum and gypsiferous clay, greenish-yellow to greenish-gray, soft Not measured

\section{TOTAKI}

[The Totaki section (lat $33^{\circ} 13^{\prime} 40^{\prime \prime}$ N., long $71^{\circ} 04^{\prime} 30^{\prime \prime}$ E.) is $1 \frac{1}{2}$ miles west-northwest of the village of Totaki (pls. 3, 5). The section was measured during the period February 9-12, 1962, by C. R. Meissner and M. A. Rashid]

Nagri Formation (Pliocene) :

Unit E. Sandstone and clay, interbedded; sandstone constitutes 80 percent of unit, light-gray with green tinge, fine-grained, very soft, calcareous, well-sorted; beds 25 to 100 feet thick, crossbedded; contains abundant black, green, and red mineral grains; weathers into large rounded and subrounded blocks, forms low hogback ridges

Unit D. Clay and sandstone interbedded; clay (60 percent), brown, brownish-red, grayishred, brown, and orange; silty but in places hard and calcareous; sandstone (40 percent), light-gray, light-brownish-gray, or brownishred, has green tinge; beds 5 to 300 feet thick. At base of unit is layer about 10 feet thick of dark-brownish-red soft sandstone; about 280 feet up from base is thin ash-colored sandstone, fine- to coarse-grained, poorly sorted, crossbedded, soft, very calcareous micaceous, containing angular and subangular quartz grains and abundant darkmineral grains. Interbedded conglomerate lenses composed of subangular to subrounded pebbles of gray clay, sandstone, quartzite, chert, limestone, and igneous rock in hard calcareous sandy matrix. Reworked small Foraminifera of possible Eocene age observed in at least one conglomerate bed.....-

Unit C. Sandstone and clay, interbedded; sandstone (70 percent) very light gray to gray, has slight green or brown tinge, mediumto coarse-grained, beds 10 to 150 feet thick, poorly sorted, generally soft, calcareous, crossbedded, jointed; consists mostly of angular to subrounded quartz grains and abundant black, brown, green, and yellow

\section{Thickness \\ (feet)} (feet)

\section{5}

Thickness

(f)et)

(

\section{Nagri Formation (Pliocene)-Continued \\ Unit C-Continued}

mineral grains. Clay (30 percent), darkbrownish-red to grayish-red, generally soft, but some layers hard and nodular, in places calcareous and silty

Unit B. Sandstone and clay, interbedded; sandstone (70 percent), light-gray, "salt and pepper," or brownish-gray to greenish-gray, generally medium- to coarse-grained, but has a few very fine grained beds, beds 10 to 300 feet or more thick, crossbedded, micaceous, calcareous, contains abundant angular to subangular dark-mineral grains; generally resistant to weathering, but joints impart "brick-wall" appearance; certain beds weather into subrounded or rounded blocks. Sandstone part of unit contains conglomerate lenses composed of rounded and subrounded pebbles of quartzite, chert, limestone, and igneous rock; forms high ridges or cliffs. Clay ( 30 percent), grayish- to reddish-brown, in places has green tinge or is mottled, silty, and calcareous; most beds are soft, and lumpy, a few have hard calcareous nodules

Chinji Formation (Pliocene) :

Unit A. Clay, brownish-red, dark-brownish-red, grayish-red, or purple; soft, calcareous, and silty; interbedded with sandstone, gray, green tinge, fine-grained, soft, calcareous, composed of quartz and black, brown, and green mineral grains; unit forms valley

\section{DAG}

[The Dag section (lat $33^{\circ} 51^{\prime} \mathrm{N}$., long $71^{\circ} 48^{\prime} 40^{\prime \prime}$ E.) is just east of the village of Dag (pl. 2). The section was measured during the period February 18-20, 1962, by J. M. Master and Muzaffar Hussain]

Thickness

Murree Formation (Miocene) :

Unit E: Sandstone, dark-brown, hard _.._Not measured Unconformity.

Kohat Formation (Eocene) :

Sadkal Member and Kaladhand Member:

Unit D. Limestone and shale; limestone, medium- to dark-gray, thin-bedded, sandy at the top, shale partings; interbedded with shale, yellow, soft, friable. Ostrea shells, early Eocene fossils; samples D12 and D11 yielded Lockhartia hunti, Nummulites spp., Radiolaria, Ostracoda Mami Khel Clay (Eocene) :

Unit C. Sandstone, brown, gritty, contains fragments of chert in sandy matrix. Limestone (8 ft) at base, brown -..........

Unit B. Clay, purple to yellowish-brown, dullred, or mottled: Calcareous in part; loose and soft. At 36 feet from top is a 15-footthick dark-brown sandstone (feet)

(feet) 
Lockhart Limestone (Paleocene) :

Unit A. Limestone, gray to dark-gray, finely to medium-crystalline, hard, nodular; shale partings in lower and upper parts, thickbedded where no shale partings; mottled shale zone about 12 feet thick at base; contains calcite veins. Paleocene fossils; sample A1 yielded Miscellanea spp.

Unconformity.

Attock Slate (Precambrian or Paleozoic) :

Slaty shale, gray Not measured

\section{PANOBA}

[The Panobs section (lat $33^{\circ} 36^{\prime} 25^{\prime \prime}$ N., long $71^{\circ} 54^{\prime} 02^{\prime \prime}$ E.) is approximately half a mile southeast of the village of Panoba (pls. 2, 4). The section was measured (date unknown) by S. M. N. Rizvi and M. R. Khan, and the following descriptions have been adapted from their report]

Kohat Formation (Eocene) :

Thicleness (feet)

Habib Rahi Limestone Member:

Unit 1. Limestone, dark-gray, finely crystalline, massive, nodular. Very fossilferous, lower Eocene; sample yielded Orbitolites complanatus, Alveolina elliptica, Flosculina globosa, Nummulites spp. Unit not complete

Sadkal Member and Kaladhand Member:

Unit 2. Limestone and shale; limestone, dark-gray, argillaceous, interbedded with shale, yellowish-brown to dusky-yellow, early Eocene fossils; sample yielded Orbitolites complanatus, Nummulites aff. N. mamilla?, Assilina granulosa

Mami Khel Clay (Eocene) :

Unit 3. Chalky dolomite 7 feet thick at top, 11 feet of shale below Clay, purple to reddish-brown, containing a layer of limestone in the middle

Shekhan Limestone (Eocene) :

Unit 4. Limestone, yellowish-gray to gray, aphanitic, massive to thin-bedded, nodular; has thin beds of gypsum 30 feet below top; 48 feet of dusky-yellow shale in middle of unit: limestone below shale contains shale partings. Oil seep between gypsum beds at top of unit. Lower contact marked by thin limestone concretion zone, may be unconformity. Very fossiliferous, lower Eocene; sample of bituminous gypsiferous shale yielded a single early Eocene specimen of Globorotalia. Another sample yielded Assilina granulosa, A. pustulosa?, Discodylina spp.

Panoba Shale (Eocene) :

Unit 5. Shale, greenish-gray to light-olive, calcareous near base, slightly silty and laminated; thin veins of calcite, stained yellow on surface in places

Patala Formation (Paleocene and Eocene) :

Unit 6. Upper part: limestone, dark-gray, finely crystalline, argillaceous, massive to thinbedded, shale partings. Paleocene fossils;
Patala Formation (Paleocene and Eocene)-Continued

Unit 6-Continued samples yielded Globogerina prolata, Globorotalia aff. G. formosa, G. soldadoensis, $G$. wilcoxensis, Lockhartia hunti, Nummulites spp. Nummulites (narrow waist), Assilina spp., A. granulosa, A. pustulosa, Discocyclina.

Lower part (base of section): shale; darkgray to black, calcareous, hard, thin-bedded; splintery, breaks into irregular pieces. Unit not complete

\section{TARKHOBI}

[The Tarkhobi section (lat $33^{\circ} 35^{\prime} 30^{\prime \prime}$ N., long $71^{\circ} 50^{\prime}$ E.) is near the village of Tarkhobi (pl. 2). The section was measured (date unknown) by S. M. N. Rizvi and $M$. R. Khan, and the following descriptions have been adapted from their description]

Thickness

Shekhan Limestone (Eocene) :

Unit 1. Limestone and shale; limestone (40 percent) gray, finely crystalline, hard, massive to thin-bedded, nodular, contains shale partings, ferruginous in part, surface has rusty coating, argillaceous in part; fossiliferous (Ostrea, in limestone), interbedded with shale ( 60 percent), greenish-gray, yellowish-gray, or gray breaks into small angular pieces

Unconformity (?): Limonitic concretion zone at contact.

197 Panoba Shale (Eocene) :

Unit 2. Shale, greenish-gray to light-olive, calcareous, silty near base

Patala Formation (Paleocene and Eocene):

Unit 3. Upper part: shale, gray to brown, calcareous, limonitic, laminated; interbedded with silty shale and thin-bedded gray limestone; fossiliferous (unidentified). Argillaceous limestone and calcareous shale, gray to dark-gray; thin-bedded, limonitic. Limestone, brownish- to dark-gray, finely crystalline, ferruginous, shale partings; fossiliferous (Nummulites irregularis and so forth) Lower part: shale, gray to dark-gray, thinbedded, splintery, calcareous, contains beds of silty shale and argillaceous limestone (fossiliferous), limestone concretions, weathers to white. Basal 65 feet is calcareous shale and argillaceous limestone, gray to dark-gray, hard, ferruginous; limestone brecciated; limestone slightly silty. Weathers blocky

Lockhart Limestone (Paleocene)

Unit 4. Limestone, light- to dark-gray, finely crystalline, aphanitic, hard, massive, contains beds of brown limestone; weathers into sharp pointed edges. Fossiliferous (unidentified); upper part more ferruginous and fossiliferous than lower. Unit not complete..-(feet)

(feet)

212 


\section{SHEKHAN NALA}

[The Shekban Nala section (lat 33०35'40" N , long $71^{\circ} 30^{\prime} 30^{\prime \prime}$ (E)) in Shekhan from Eames (1952, p. 166-167, 170]

Murree Formation (Miocene) : Covered _..._.. Not measured Kohat Formation (Eocene) :

Habib Rahi Limestone Member:

Unit 1. Limestone, cream, medium-crystalline, massive; surface rubbly; highly fossiliferous (Foraminifera) -...Sadkal Member and Kaladhand Member:

Unit 2. Shale and limestone, upper 190 feet shale; highly fossiliferous (Nummulites, abundant), underlain successively by 30 feet of limestone and 30 feet of shale _-

Mami Khel Clay (Eocene) :

Unit 3. Argillaceous limestone (15 ft) containing Ostrea. Dolomite (5 ft) containing Planorbis at the base -.--

Unit 4. Clay, dark-red to dull-red, soft, weathered surface brownish-red

Shekhan Limestone (Eocene) :

Unit 5. Upper 30 feet is gypsiferous shale; remainder limestone, yellowish-g r a y, massive to thin-bedded, nodular, contains fossils (unidentified)

Panoba Shale (Eocene) :

Unit 6. Shale, greenish-gray to light-olive, slightly silty, laminated. Unit not complete _...

\section{SIGNIFICANT DEPOSITIONAL FEATURES}

Tertiary formations in the crestal parts of the Cherat Mountains seem to overlie the Attock Slate by original deposition, not by faulting; this suggests that the Attock Slate forms the root of an ancient platform, most of which may have been above water level until Paleocene time. A thin cover of Tertiary sediments was deposited on top of the Attock Slate, and the region has since been elevated and partially eroded.

The Lower Jurassic Datta Formation undergoes lateral facies changes. In the Surghar Range, it is a variegated (red, green, gray) rock sequence composed of interbedded sandstone, shale, and limestone. In the north, about 8 miles southwest of the Marai Bala section near the western border of the Kohat quadrangle, the Datta Formation is red shale in the lower part, becoming limestone upward in the section. At Marai Bala, the Datta Formation is limestone, but is slightly shaly in the lower part. About 35 miles due east of the Marai Bala section the Datta Formation is exposed on the north flank of the Kohat Range. Here, it is composed of very hard fissile acicular variegated gray, brown, and red shale with dark- gray sandstone at the base. Farther east about 22 miles, at the Mazari Tang section near the eastern border of the Kohat quadrangle, the only Jurassic rock exposed is a part of the Datta Formation which is limestone with thin shale layers in the lower part. The predominance of limestone at the Marai Bala and Mazari Tang sections, both within the Kohat Range, as opposed to the predominance of clastic rocks on the flanks of the Kohat Range and elsewhere in the region, suggests a more open marine environment of deposition of the Lower Jurassic Datta Formation in the area now occupied by the Kohat Range. This postulation is supported by the fact that most of the outcrops of rocks of Jurassic age mapped within the Kohat Range are limestone.

The Lower Cretaceous Lumshiwal Sandstone undergoes a marked facies change from west to east. On the west, it is pure quartzose sandstone, whereas on the east only a fraction of this rock type remains, and most of the formation is glauconitic thin-bedded ffaggy sandstone. This facies change suggests nearshore shelf deposition on the west, compared with deeper water conditions on the east. There is an unconformity between the Lower Cretaceous Lumshiwal Sandstone and the Upper Cretaceous Darsamand Limestone, except at the Mazari Tang section in the northeastern part of the region where the Lumshiwal Sandstone is transitional to the overlying Darsamand Limestone. This also suggests a west-to-east basinward component in rocks of Cretaceous age. This direction of deposition, from west to east, is also suggested by conditions at the contact between the Upper Cretaceous Darsamand Limestone and the overlying Hangu Formation of Paleocene age. The contact is found to be unconformable from the Uch Bazaar section westward, but transitional northward to Marai Bala and eastward to Mazari Tang. The Darsamand Limestone of Late Cretaceous age is absent in the Surghar Range far to the south. This suggests that the Surghar Range was elevated during Late Cretaceous time and marks the southern limit of the basin at that time.

An east and possibly north component direction of deeper waters is indicated by the Paleocene Hangu Formation. In the western part of the Kohat quadrangle, the Hangu Formation is entirely sandstone, whereas at sections studied to the north and east, the Hangu Formation becomes shale or limestone. The Dhak Pass Formation, equivalent to the Hangu Formation in the Surghar Range to the south, is sandstone. The overlying Paleocene Lockhart Limestone is a very persistent marker bed, but it thickens northeastward from the equivalent limestone section 
in the Surghar Range. In turn, the Paleocene and Eocene Patala Formation also becomes thicker to the east and changes from shale to mostly limestone. A striking exception to this generalization is seen in the northeastern corner of the Kohat quadrangle, where the thinnest section of Paleocene overlies At tock Slate. Apparently, during part of Paleocene time, the Attock platform subsided, allowing for the deposition of at least a thin layer of Paleocene rocks.

The top of the lower Eocene Panoba Shale is marked by an unconformity. At the Uch Bazaar section, near the western boundary of the Kohat quadrangle, tho Panoba Shale is in contact with the overlying Kohat Formation, also of early Eocene age. This marks a hiatus, because in sections to the east, first the Mami Khel Clay and then the Shekhan Limestone come between the Panoba Shale and Kohat Formation. There seems to be a full thickness of Panoba Shale at Uch Bazaar, so that the unconformity may reflect nondeposition rather than erosion. At the Dag section, however, on top of the Attock Slate, the Shekhan Limestone and Panoba Shale are missing; this may result from erosion due to temporary uplift of that area. There are, therefore, two shorelines on the west-east line from Uch Bazaar to the Panoba section: that of the lower Eocene Mami Khel Clay between Uch Bazaar and the Chilli Bagh section,- and that of the Shekhan Limestone between Chilli Bagh and the Shekhan Nala sections. The strike of the "shorelines," as evidenced by work to the south, is approximately northeast, the basin being toward the south. The Panoba Shale shows a remarkable facies change from north to south. Along the northern part of the Eocene belt of rocks, the Panoba is shale; to the south its position is occupied by rock salt. In the Surghar Range, about 45 miles to the south, the Panoba Shale is equivalent to part of the Sakesar Limestone. The area of the Surghar Range must have subsided from the relatively high position that it occupied until Paleocene time. The presence of the thick Sakesar Limestone of early Eocene age indicates deposition in open marine waters.

The Shekhan Limestons in the northern part of the Eocene belt of rocks changes southward into gypsum (Jatta Gypsum) and salt within most of the area of outcropping formations of Eocene age. At the Surghar Range, the Shekhan Limestone correlates with the upper part of the Sakesar Limestone. The gypsum and salt were formed in an evaporitic basin or arm of the sea during early Eocene time. It is not understood at this time what conditions permitted limestone and shale deposition to the north, limestone deposition to the south, and evaporites in the middle. Evidently, some physical barrier such as a reef had enclosed a part of the sea, causing the extreme saline environment in which gypsum and salt formed.

The lower Eocene Mami Khel Clay, an excellent marker bed found above the Shekhan Limestone or Jatta Gypsum, is absent in the Surghar Range, probably owing to erosion, because eastward from the Surghar in isolated depressions the Mami Khel Clay is seen overlying gypsum.

The top of the Kohat Formation (top of the lower Eocene) is marked by a widespread unconformity. Overlying the Kohat Formation is the Murree Formation of Miocene age. The unconformity is largely due to nondeposition of younger Eocene sediments, but some erosion also has taken place at the top of the Kohat Formation. There is no upper Kohat Formation (Habib Rahi Limestone Member) at Dag where the lower Eocene-Miocene unconformity is at the top of the lower Kohat Formation (Kaladhand Member) ; in the Surghar Range there is no evidence that the Kohat Formation was ever deposited. In the south-trending extension of the Surghar Range (Makerwal area), the top of the Sakesar marks an unconformity between the lower Eocene and the Oligocene(?) Mitha Khatak Formation. This formation, as described by Walter Danilchik and S. M. I. Shah (unpub. data, 1965), has not been found to the north; rather it correlates with the Kamlial Formation in the Surghar Range north of the area mapped by Danilchik and Shah.

The edge of the Miocene basin (Murree Formation) is near the southwestern part of the Kohat quadrangle. At Banda Daud Shah, there is almost no Murree Formation; it increases in thickness in the north and east part of the region where there are extensive outcrops. The Murree Formation is several thousand feet thick at the town of Murree east of the Kohat quadrangle. Deposition took place in a northeastward basinward direction again as opposed to the southward direction indicated in at least the early part of Eocene time. There is no Murree Formation in the Surghar Range, which must have been a positive area at the time of Murree Formation deposition.

At Banda Daud Shah, the contact of the Kamlial Formation of Miocene age with the overlying Chinji Formation of Pliocene age is believed to be unconformable. This unconformity extends down to the top of the Mitha Khatak Formation in the Makerwal area of the Surghar Range, where only eroded pieces of the Kamlial are found on top of the Mitha Khatak. 
At the top of the Nagri Formation of Pliocene age at Hukni near the southeastern part of the region, a thick sequence of cobble beds is a lateral facies of the Dhok Pathan Formation. A thick section of Nagri Formation at Totaki on the western side of the Kohat quadrangle suggests a nearby source and rapid deposition in a trough.

E. B. Fritz supplied the palentological information for this report from rock samples sent to him by the authors and has made some conclusions upon the completion of his work. The following information is a summary of these conclusions (E. B. Fritz, written commun., 1962) :

The Jurassic rock probably was deposited in deep water, because only benthonic fossils were found in the samples. The Upper Cretaceous rock was deposited in clear, possibly warm water which was too deep to permit the existence of shallow water forms. Planktonic fossil forms indicate that deposition was under open-sea conditions, or in an area which has direct access to the open ocean. Deposition probably was under shelf conditions, not bathyl. The Paleocene contains an abundance of shallow water larger Foraminifera and a relatively few planktonic forms. On the basis of the samples examined, it seems that little of the Paleocene was deposited in the open sea. Deposition of most of the Paleocene was in warm, clear, shallow water, and in areas which had limited access to the open sea so that currents carrying the planktonic forms could enter only rarely. Ordinarily, planktonic forms are abundant in the marine Tertiary of Pakistan; some physical barrier, possibly a reef, must have prevented access of the planktonic Foraminifera in the Paleocene environment of the Kohat quadrangle. The barrier also could have been in the form of a narrow, restricted passage. The depositional conditions believed to have taken place in Paleocene time were duplicated in early Eocene time: deposition in warm, shallow water, and in areas which had only occasional access to the open sea.

Fritz concluded that the seas covering the area of deposition of the samples examined were deepest in the Jurassic, somewhat shallower in the Cretaceous, and became progressively shallower throughout the Paleocene and the early Eocene. He also stated that very likely the basin of deposition was more restricted in Paleocene and early Eocene time than in Cretaceous time.

\section{REFERENCES CITED}

Burnes, A., 1832, Some account of the salt mines of the Punjaub: Asiatic Soc. Bengal Jour., v. 1, 145-147.

Danilchik, Walter, 1961, The iron formation of the Surghar and western Salt Ranges, Mianwali District, West Pakistan: U.S. Geol. Survey Prof. Paper 424-D, p. D228D231.

Davies, L. M., 1926, Notes on the geology of Kohat, with reference to the homotaxial position of the salt marl at Bahadur Khel: Asiatic Soc. Bengal Jour. and Proc., new ser., v. 20, p. 207-224.
1930, The fossil fauna of the Samana Range and some neighboring areas; Part I, An introductory note: India Geol. Survey Mem., Palaeontologia Indica, new ser., v. $15,15 \mathrm{p}$.

1940, The upper Khirthar beds of northwest India: Geol. Soc. London Quart. Jour., v. 96, pt. 2, no. 382, p. 199-230.

1943, Tertiary Echinoidea of the Kohat-Potwar basin [India]: Geol. Soc. London Quart. Jour., v. 99, pt. 1-2, no. 393-394, p. 63-79.

Davies, L. M., and Pinfold, E. S., 1937, The Eocene beds of the Punjab Salt Range: India Geol. Survey Mem., Palaeontologia Indica, new ser., v. 24, no. 1, 79 p.

Eames, F. E.. 1952, A contribution to the study of the Eocene in western Pakistan and western India; Part A, The geology of standard sections in the western Punjab and in the Kohat District: Geol. Soc. London Quart. Jour., v. 107, pt. 2, no. 426, p. 159-171.

Fleming, Andrew, 1853, Report on the geological structure and mineral wealth of the Salt Range in the Punjaub: Asiatic Soc. Bengal Jour., v. 22, p. 229-279, 333-368, 444-462; Geol. Soc. London Quart. Jour., v. 9, pt. 3, p. 189-200.

Gee, E. R., 1935, General report for 1934-The western part of the Salt Range: India Geol. Survey Recs., v. 69, pt. 1, p. 67.

1938, The economic geology of the northern Punjab, with notes on adjoining portions of the North West Frontier province [with discussion]: Mining Geol., and Metall. Inst. India Trans., v. 33, pt. 3, p. 263-354.

1945, The age of the Saline series of the Punjab and of Kohat: Natl. Acad. Sci. India Proc., Sec. B, v. 14, pt. 6, p. 269-310.

Gill, W. D., 1951, The stratigraphy of the Siwalik series in the northern Potwar, Punjab, Pakistan: Geol. Soc. London Quart. Jour., v. 107, pt. 4, no. 428, p. 375-394.

Haque, A. F. M. M., 1956, The Foraminifera of the Ranikot and the Laki of the Nammal Gorge, Salt Range: Pakistan Geol. Survey Mem., Palaeontologia Pakistanica, v. $1,300 \mathrm{p}$.

Karsten, C. J. B., 1846, [The salt mines of Kohat(?)], in Lehrbuch der Salinenkunde: Berlin.

Lewis, G. E., 1937, A new Siwalik correlation [India]: Am Jour. Sci., ser. 5, v. 33, no. 195, p. 191-204.

Meissner, C. R., Hussain, Muzaffar, Rashid, M. A., and Sethi, U. B., 1973, Geology of the Parachinar quadrangle, Pakistan: U.S. Geol. Survey Prof. Paper 716F. (In press.)

Middlemiss, C. S., 1896, The geology of Hazara and the Black Mountains: India Geol. Survey Mem., v. 26, $302 \mathrm{p}$.

Oldham, R. D., 1892, Report on the geology of Thal-Chotiali and part of the Mari country: India Geol. Survey Recs., v. 25 , pt. 1, p. 18-29.

Oldham, Thomas, 1864, Memorandum on the results of a cursory examination of the Salt Range and parts of the Districts of Bannu and Kohat with a special view to the mineral resources of those districts: Recs., Govt. India, v. 64, p. $126-156$.

Pilgrim, G. E., 1910, Preliminary note on a revised classification of the Tertiary freshwater deposits of India: India Geol. Survey Recs., v. 40, pt. 3, p. 185-205. 
1913, The correlation of the Siwaliks with mammal horizons of Europe: India Geol. Survey Recs., v. 43, p. 264-326, pls. 26-28.

Pinfold, E. S., 1918, Notes on structure and stratigraphy in the northwest Punjab: India Geol. Survey Recs., v. 49, p. 137-160.

Rashid, M. A., Hussain, Muzaffar, Master, J. M., and Meissner, C. R., 1965, Mineral deposits of the eastern Kohat region, West Pakistan: Pakistan Geol. Survey Recs., v. 13, pt. 2, 16 p.

Rizvi, S. M. N., and Khan, M. R., [1955?], Panoba and Tarkhobi measured sections: Pakistan Geol. Survey open-file rept.

Stratigraphic Committee of Pakistan, 1964a, Minutes of the 6th meeting [February]: Pakistan Geol. Survey openfile rept. 1964b, Minutes of the 7th meeting [April]: Pakistan Geol. Survey open-file rept.

Wynne, A. B., 1874, Notes on the geology of the neighbourhood of Mari hill station in the Punjab: India Geol. Survey Recs., v. 7, pt. 2, p. 64-74. - 1875, The Trans-Indus salt region in the Kohat district: India Geol. Survey Mem., v. 11, pt. 2, p. [105-330].

1877, Note on the Tertiary zone and the underlying rocks in the north-west Punjab: India Geol. Survey Recs., v. 10, pt. 3, p. 107-132.

1879 , A geological reconnaissance from the Indus at Kushalgarh to the Kurram at Thal on the Afghan frontier: India Geol. Survey Recs., v. 12, p. 100-114.

Wynne, A. B., and Waagen, W., 1872, Geology of Mount Sirban in the upper Punjab: India Geol. Survey Mem., v. 9, p. 331-350.

t U.S. GOVERNMENT PRINTING OFFICE: 1974 O-585-465/17 